\title{
Significance of the tuffaceous beds associated with the Bijaigarh Shale of the Kaimur Group, Vindhyan Supergroup, Central India and their correlation with tuffs in other contemporaneous Proterozoic basins
}

\author{
Shinjana Sen ${ }^{1}$ and Meenal Mishra ${ }^{2} *$ (0) \\ ${ }^{1}$ Department of Geology, Centre of Advanced Study, University of Delhi, Delhi 110 007, India. \\ ${ }^{2}$ School of Sciences, Indira Gandhi National Open University, New Delhi, India. \\ *Corresponding author. e-mail: meenalmishra@ignou.ac.in
}

MS received 10 December 2018; revised 1 April 2019; accepted 10 April 2019

Bijaigarh Formation is lithologically heterogeneous with grain size varying from fine to medium sand to clay. About $\sim 1 \mathrm{~m}$ thick tuffaceous beds of rhyolitic to rhyodacitic nature, sandwiched between the Bijaigarh siliciclastics have been reported. We have attempted to distinguish the tuffaceous beds from the adjacent terrigenous sediments of Bijaigarh Shale on the basis of their field disposition, petrographic and geochemical characteristics. The tuffs are characterised by a relatively high content of LILE, HFSE and LREE as compared to Bijaigarh siliciclastics. They reflect their affinity to the felsic magmatic source. The geochemical signatures of the Bijaigarh tuff exhibit quite comparable characters to the contemporaneous ( 1000 Ma) tuffs from other Proterozoic basins, viz., Chhattisgarh and Indravati. The extrabasinal sources for the deposition of the Bijaigarh tuff at $\sim 1000$ Ma can be inferred which can possibly be correlated with tectonothermal events of the Grenville orogeny. The integration of elemental compositions with mineralogical and textural observations makes possible the establishment of the tuffaceous beds as a stratigraphic marker in the Upper Vindhyan stratigraphy. This will have wider implications for the precise and reliable correlations of the Proterozoic basins of India.

Keywords. Volcanic ash beds; tuff; Bijaigarh Shale; Kaimur Group; Proterozoic basins.

\section{Introduction}

Volcanic ash or tuff layers within the monotonous sedimentary sequences provide the remarkable stratigraphic marker beds. The explosive volcanic eruptions can produce large amounts of finegrained material which spread laterally and the resulting fallout of ash tends to cover the preeruptive topography of the depositional surfaces. Tuffs have been reported from the majority of the Proterozoic basins of the Indian subcontinent, viz., Sukhda tuff (Patranabis Deb 2003; Subba Rao Published online: 05 August 2019 et al. 2006; Patranabis Deb et al. 2007; Basu et al. 2008; Bickford et al. 2011a), Dhamda tuff (Bickford et al. 2014) and the Singhora tuff from Chhattisgarh (Das et al. 2009). Tuffs have also been reported from Proterozoic basins like the Pranhita-Godavari (Chaudhuri and Chanda 1991; Saha and Ghosh 1998; Patranabis Deb 2003), Cuddapah basin (Dasgupta and Biswas 2005; Goswami et al. 2018), Kurnool (Saha and Tripathy 2012) and the Indravati and Sukma basins (Mukherjee et al. 2012; Bickford et al. 2014). The Vindhyan basin in central India has also been 
punctuated by tuffaceous beds at different stratigraphic levels (Soni et al. 1987; Chakraborty et al. 1996, 2010; Bose et al. 2001). The extensively investigated Porcellanite Formation of the Semri Group/Lower Vindhyan comprises volcanic ash and tuffaceous beds which are the product of intrabasinal volcanism deposited in the subaqueous/subaerial environment (Auden 1933; Roy and Banerjee 2001; Srivastava et al. 2003; Chakrabarti et al. 2007; Mishra and Sen 2008; Sen and Mishra 2014; Bickford et al. 2017; Mishra et al. 2017a, b, c, 2018). The volcaniclastic inputs at the basal part of the Kaimur Group and at different stratigraphic levels within the Rewa Group from the Vindhyan basin have been reported by Chakraborty et al. (1996, 2010).

The present study was carried along the Son valley in the area located in the northern part of Sonbhadra district of Uttar Pradesh in central India (figure 1). The present communication, for the first time, reports the volcanic ash/tuffaceous beds sandwiched within the sedimentary layers of Bijaigarh Formation of Mesoproterozoic Kaimur Group, Vindhyan Supergroup. The field observations, petrographic, mineralogical and geochemical studies indicate that the tuffs associated with the Bijaigarh Shale are of igneous origin. We have also attempted to correlate the geochemical signatures of Bijaigarh tuff with the tuffs from other contemporaneous Proterozoic basins.

\section{Geological setting}

The Vindhyan Supergroup consists of a thick repository $(\sim 4500 \mathrm{~m})$ of sedimentary rocks deposited in the largest intracratonic basin of India (Valdiya et al. 1982; Soni et al. 1987; Bhattacharya 1996). This supergroup has been divided into four groups which comprise (in ascending order) the Semri, the Kaimur, the Rewa and the Bhander groups (Auden 1933; Prakash and Dalela 1982). Son valley sector classically exposes two groups, i.e., older Semri and the younger Kaimur (figure 2) of the Vindhyan supergroup. The Kaimur group consists of a huge pile (thickness $\sim 400 \mathrm{~m}$ ) of siliciclastics which unconformably overlie tilted, mildly deformed and partially eroded Rohtas formation which is the uppermost carbonate rich unit of the Semri group (figure 3). In fact, the Kaimur group unconformably overlies all the formations of the Semri group along the Markundi-Jamwal fault (figure 2). The Semri-Kaimur boundary is considered as a distinctive shift from the calcareous

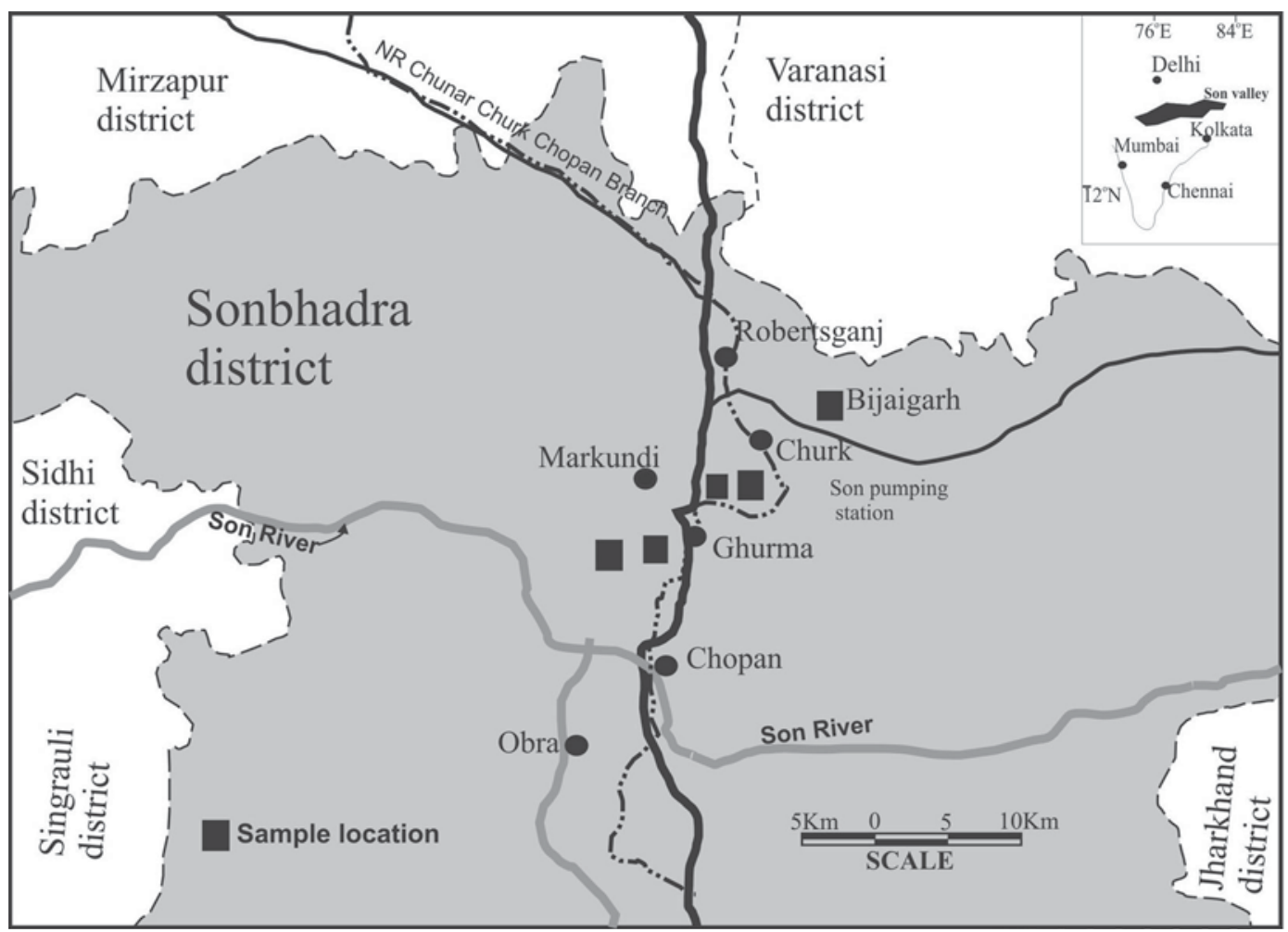

Figure 1. Sample location map showing the northern part of the Sonbhadra district, Uttar Pradesh. Filled square marks sample location. 


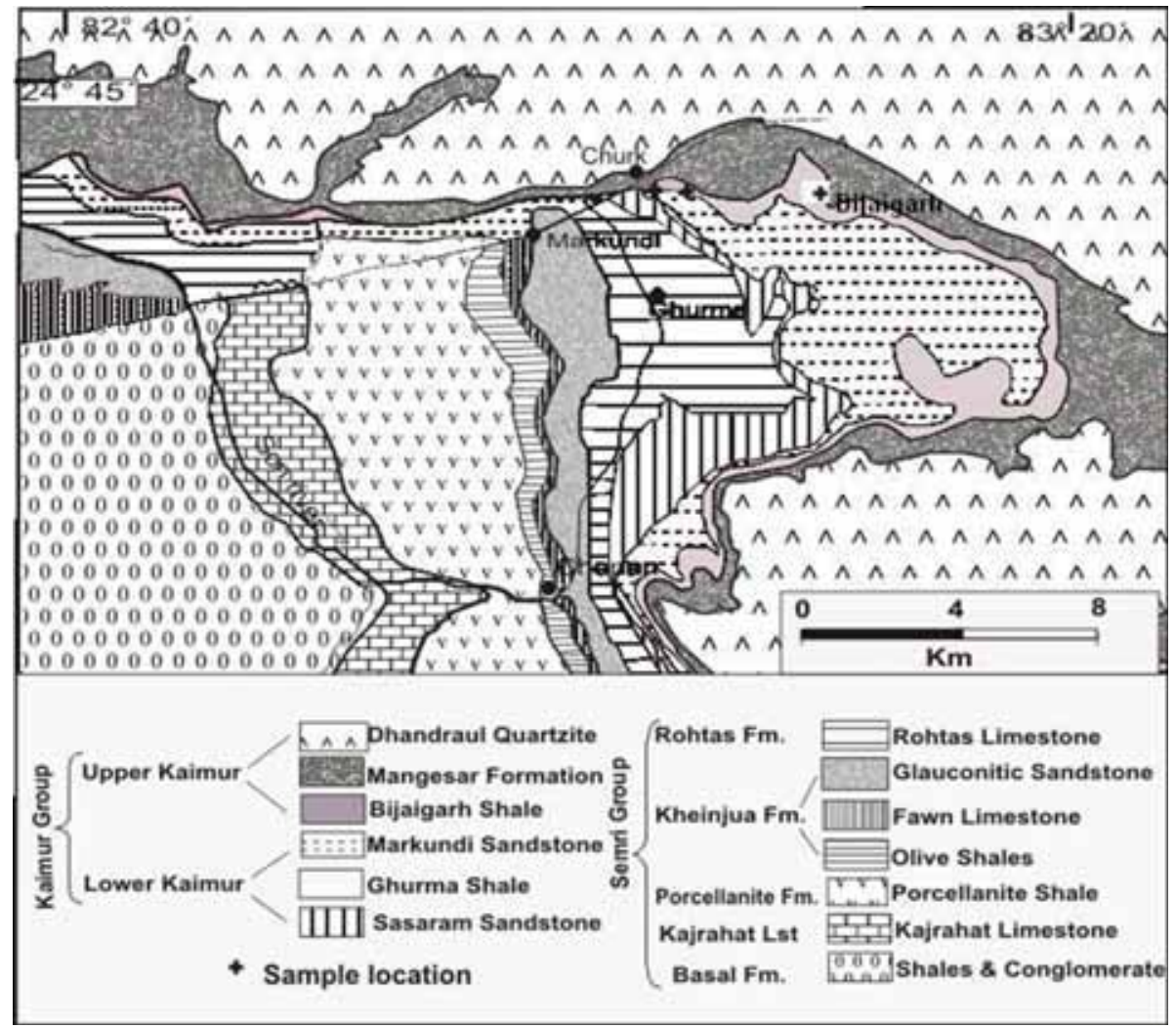

Figure 2. Geological map of the study area in the eastern part of the Son valley (modified after Auden 1933).

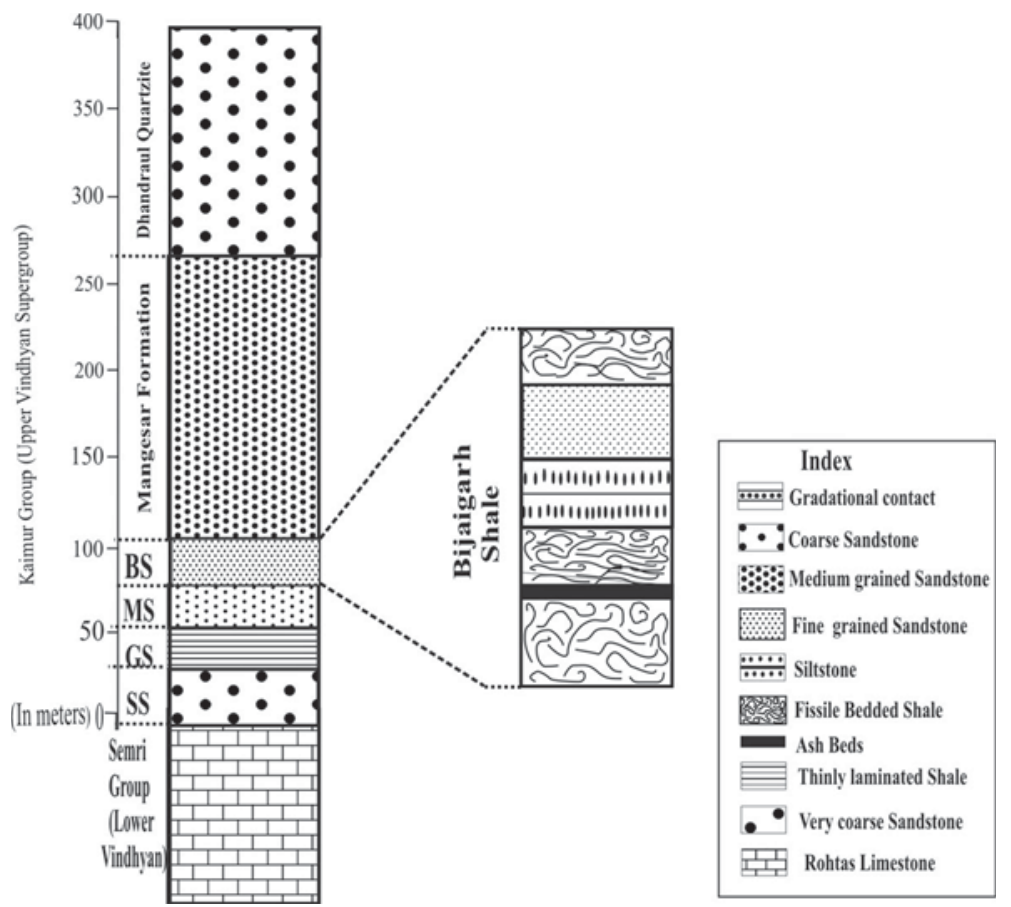

Figure 3. Generalised lithology of the Kaimur group. SS: Sasaram sandstone; GS: Ghurma shale; MS: Markundi sandstone; BS: Bijaigarh shale.

(Rohtas limestone) to a silica-rich environment during the deposition of Kaimur siliciclastics. The Kaimur group has been divided into six formations (arranged in stratigraphic order) comprising the oldest Sasaram Sandstone, Ghurma Shale, Markundi Sandstone, Bijaigarh Shale, Mangesar 
Table 1. Generalised stratigraphic succession of the Vindhyan supergroup in the Son valley, central India (modified from Prakash and Dalela 1982). References for ages are given in the table.

\begin{tabular}{|c|c|}
\hline Group with thickness & Formation with thickness and available ages \\
\hline $\begin{array}{l}\text { Kaimur group/Upper } \\
\text { Vindhyan }(400 \mathrm{~m})\end{array}$ & $\begin{array}{l}\text { Dhandraul Quartzite }(100 \mathrm{~m}) \\
\text { Mangesar Formation }(155 \mathrm{~m}) \\
\text { Bijaigarh Shale }(50 \mathrm{~m}) \\
\text { Markundi Sandstone }(40 \mathrm{~m}) \\
\text { Ghurma Shale }(16 \mathrm{~m}) \\
\text { Sasaram Sandstone }(30 \mathrm{~m}) \\
\text { 1070 } 160 \text { Ma (Srivastava and Rajagopalan } 1988) \\
\text {-------------- Unconformity/normal contact--------- }\end{array}$ \\
\hline $\begin{array}{l}\text { Semri group/Lower } \\
\text { Vindhyan (3000-4000 m) }\end{array}$ & 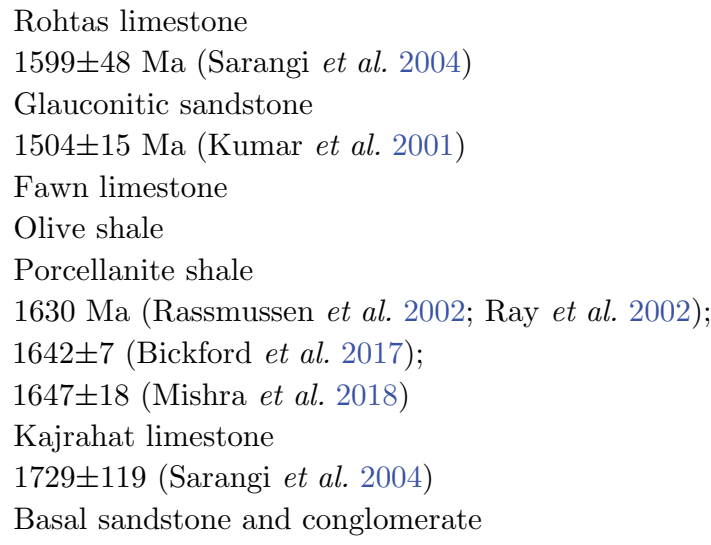 \\
\hline \multicolumn{2}{|c|}{$\begin{array}{l}\text { Mahakoshal Group/Jhirgadandi granite } \\
1753 \pm 9 \text { Ma (Bora et al. 2013) }\end{array}$} \\
\hline
\end{tabular}

Formation and the youngest Dhandraul Quartzite (Auden 1933; Prakash and Dalela 1982; table 1 and figure 3). These formations have been petrologically and geochemically characterised by Sen (2010), Mishra and Sen (2011, 2012, 2015) and Sen et al. (2014).

Vindhyan sedimentation initiated before 1700 $\mathrm{Ma}$ and continued shortly after $1000 \mathrm{Ma}$ (Sarangi et al. 2004; Gregory et al. 2006). However, the upper limit for the closure of the Vindhyan basin has been bracketed down to $1000 \mathrm{Ma}$ by Malone et al. (2008) and Turner et al. (2014). This is supported by the $\mathrm{Pb}-\mathrm{Pb}$ isochron ages ranging from 980 to $1073 \mathrm{Ma}$ (Gopalan et al. 2013) for the topmost limestone beds of the Vindhyan succession. The $\mathrm{Pb}-\mathrm{Pb}$ isochron age of $750 \pm 50$ for Bijaigarh shale has been given by Balasubramanyan and Chandy (1976). However, the Re-Os depositional age for Bijaigarh shales from the Kaimur group has been given as $1210 \pm 52 \mathrm{Ma}$ by Tripathy and Singh (2015).

The siliciclastics of the Kaimur group were initially deposited in the transgressive environment followed by the regressive phase in the upper part, of the Vindhyan shallow sea (Bose et al. 2001). The
Bijaigarh shale has been considered to have been deposited in a lagoonal environment with access to open sea (Singh 1980). Bijaigarh shale exhibits lithological heterogeneity, with variation in grain size from fine to medium sand, silt and clay. The shales are buff to brownish and reddish in colour. The micaceous minerals can be observed in hand specimen. The maximum thickness of these shales is about $50 \mathrm{~m}$. The generalised lithology of the Kaimur group is shown in figure 3. In the study area, it comprises shales, mudrocks and finely laminated carbonaceous black shales (Paikaray et al. 2003; Banerjee et al. 2006). They are friable in nature with fissile bedding giving a crinkled appearance to the outcrop (figure 4). Sedimentary structures like ripple marks, current bedding and orthogonal sun cracks are abundant.

Interestingly, we observed that the tuffaceous/ indurated ash beds $(\sim 1 \mathrm{~m}$ thick) are intimately associated with the Bijaigarh shale. Their outcrops comprise a distinct and conspicuous horizon characterised by very fine-grained, hard and compact, olive green, buff or grey thinly ash beds or bedded tuff layers. They break along curved and smooth surfaces (perlitic cracks). On the basis of physical 


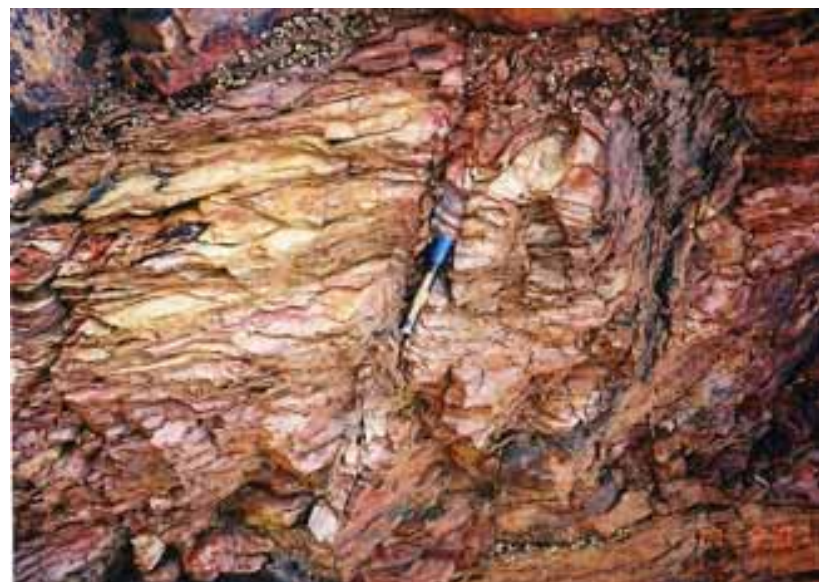

Figure 4. Crumpled and folded Bijaigarh shale. Notice the reddish colour of the outcrop.

appearance, these tuffaceous beds could be easily distinguished from the overlying and underlying carbonaceous black to buff to bleached soft and friable Bijaigarh shale (figure $5 \mathrm{a}$ and b). Their lateral extension was traced in Markundi Ghat section and on both sides of the highway from Varanasi to Chopan before Markundi, near Son pumping station at Churk and near Bijaigarh fort (figures 2 and $5 \mathrm{~b}$ ). For the purpose of present study, the tuffaceous beds associated with Bijaigarh shale have been referred as Bijaigarh tuff.

\section{Sampling and analytical techniques}

Relatively fresh and compact samples were collected from the middle part of the tuff beds, thus avoiding contamination from adjacent Bijaigarh siliciclastics as far as possible. The sampling of tuffaceous beds was carried out from Markundi Ghat, Son pumping station and the southern slope of the Bijaigarh fort (figure $5 \mathrm{a}$ and $\mathrm{b}$ ). The samples from Bijaigarh shale were systematically collected based on the lithological variation. The bulk samples were reduced to small chips and powdered to -60 mesh size. After homogenisation, about $100 \mathrm{~g}$ of each sample was ground to less than -200 mesh size, using the pulveriser malle RETSCH and Agate Mortar Pestle at Banaras Hindu University, Varanasi. The powdered samples were used for $\mathrm{X}$-ray powder diffraction (XRD) and geochemical analysis. The XRD pattern for each sample was recorded using a Rigaku DMAX III diffractometer at Banaras Hindu University, Varanasi. The powdered samples were scanned from $9^{\circ}$ to $76^{\circ} 2 \theta$ with a scanning speed of $0.05^{\circ} / \mathrm{s}$. Minerals were identified by using JCPDS data file of 1987 .
A total of 18 samples (10 and 8 samples from Bijaigarh tuff and Bijaigarh siliciclastics, respectively) were analysed for major, trace and rare earth element (REE) compositions. The geochemical analysis was carried out at the Geochemistry Division of the National Geophysical Research Institute (NGRI), Hyderabad. $0.1 \mathrm{~g}$ of sample powder was taken in a Teflon beaker to which $7 \mathrm{ml}$ of $\mathrm{HF}(48 \%), 3 \mathrm{ml}$ of conc. $\mathrm{HNO}_{3}$ and $1 \mathrm{ml} \mathrm{HClO}_{4}$ were added. This mixture was digested by keeping the beaker over a hot plate. After confirming complete digestion, $10 \mathrm{ml}$ of $\mathrm{HNO}_{3}$ of $1: 1$ concentration was added and was kept on hot plate until a clear solution was obtained. When the solution had cooled down, the volume was brought to $100 \mathrm{ml}$ with double distilled water after adding $10 \mathrm{ml}$ of 1 ppm rhodium solution as an internal standard (Balaram et al. 1996). ICP-mass spectrometer model ELAN dynamic reaction cell (DRC) II (PerkinElmer Sciex Instrument, USA) was used for analysis. The instrument is equipped with the state-of-the-art features such as the DRC and other technical advancements leading to extremely low background, better sensitivity and precision. The detection limit for most of the elements is in $\mathrm{pg} / \mathrm{ml}$ (ppt) and $\mathrm{fg} / \mathrm{ml}(\mathrm{ppq})$ level. The system was optimised for maximum intensity ( $\sim 40,000$ counts/s) across the mass range $1 \mathrm{ng} / \mathrm{ml}$ solution of $\mathrm{Mg}, \mathrm{Rh}$, $\mathrm{In}, \mathrm{Ba}, \mathrm{Ce}, \mathrm{Pb}$ and $\mathrm{U}$. International rock standards GSR-4 and GSR-5 were used as the external reference material. The precision of REE and trace element data are better than 5\% RSD with comparable accuracies (Balaram et al. 1996, 1999). Out of 10 tuff samples, 2 (the number needed to treat (NNT-1, NNT-2) were analysed at Activation Laboratory, Canada using inductively coupled plasma atomic emission spectroscopy (ICP-AES) (model - Thermo Jarret Ash ENVIRO II) for major oxides and for trace and REE concentrations, inductively coupled plasma mass spectrometry (ICP-MS) (model: Perkin Elmer Sciex Elan $6000)$. The precision is $<5 \%$ for all analysed elements when reported at a $100 \times$ detection limit for the samples analysed from Actslab.

The normalised values used are taken from Sun and McDonough (1989). The values for postArchaean Australian Shale (PAAS) and Upper Continental Crust (UCC) have been taken from Condie (1993). Major oxide and trace element data including REE are presented in table 2. In the present study, the published geochemical data of contemporaneous rhyolitic tuffs of $\sim 1000 \mathrm{Ma}$ age from the Indravati basin (Mukherjee et al. 2012) 

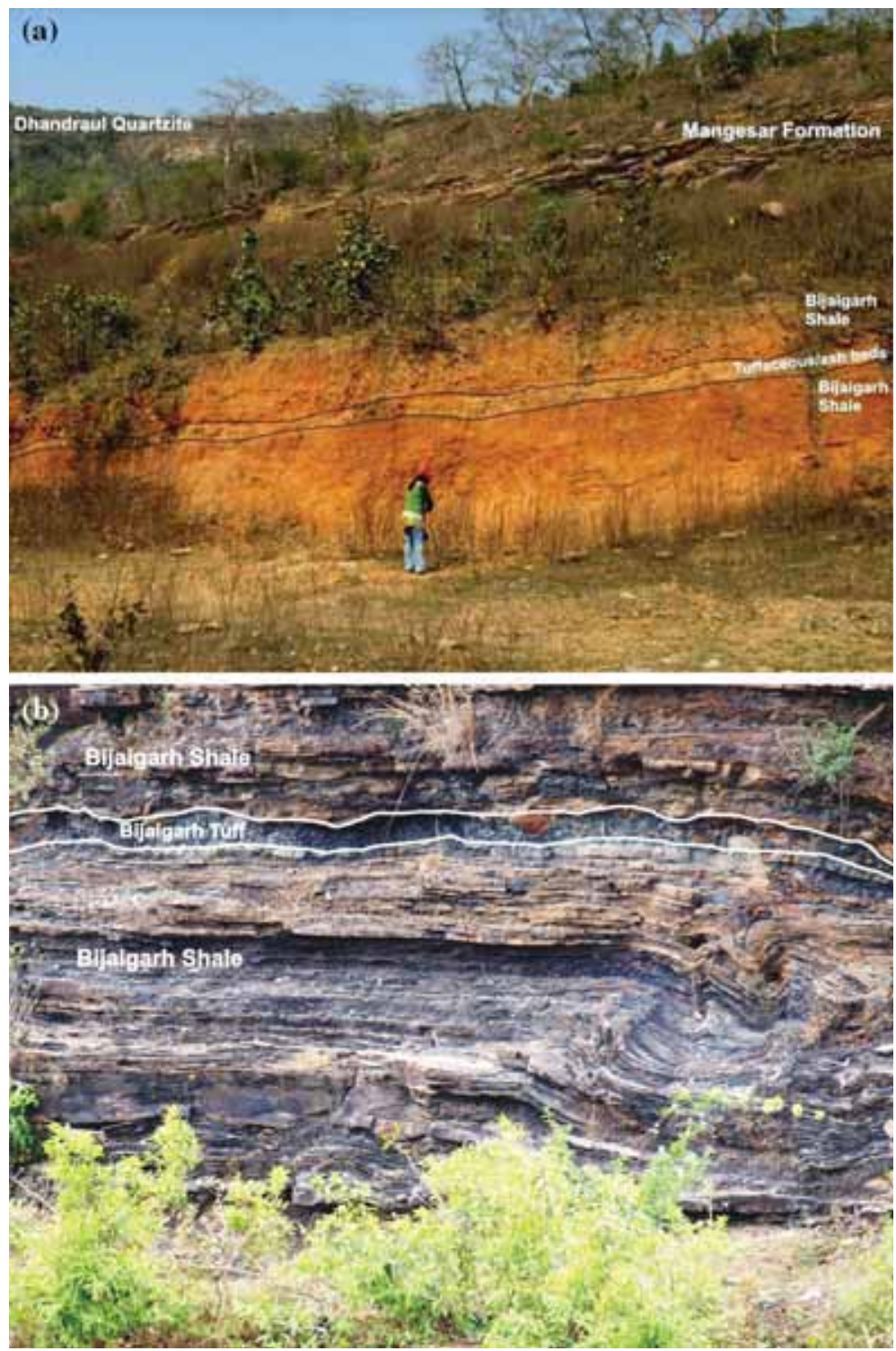

Figure 5. Field photograph showing tuffaceous/ash beds sandwiched within the Bijaigarh Shale. (a) Markundi Ghat section; and (b) Bijaigarh section.

and Sukhda (Bickford et al. 2011b) and Dhamda (Basu et al. 2008) from the Chhattisgarh basin were obtained. Das et al. (2009) have reported ages of $\sim 1500 \mathrm{Ma}$ of tuff from Singhora of the Chhattisgarh succession. Data for comparison for Sukhda, Indravati and Dhamda tuff have been obtained from Bickford et al. (2014). The geochemical data of Singhora tuff (Das et al. 2009) have been considered for comparison.

\section{Petrography}

The petrographic study was carried out under a high-resolution Leica DMRX microscope. Thin section study of Bijaigarh tuff reveals the highly welded nature, aphyric and vitrophyric texture. Quartz, K-feldspar, albite and muscovite occur as phenocrysts. Accessory minerals include euhedral zircon, rutile, ilmenite mica and opaques. Quartz phenocrysts consist of embayed or bipyramidal crystals (figures $6 \mathrm{a}$ and 7 ). The primary relict igneous texture is evidenced by the presence of fine-grained vitric fragments and devitrified cuspate and sickle-shaped glass shards in association with the abundance of altered clay minerals which are set in a vitrophyric groundmass. They may be categorised as vitric tuff (Schmid 1981). The tuffs are vitric to crysto-vitric in nature. Due to their very fine-grained nature, tuff has undergone alteration to clay minerals identified as illite. However, few grains of quartz, feldspar and glass shards have 
Table 2. Major oxide, trace and REE data of tuffaceous ash beds and Bijaigarh siliciclastics, Kaimur Group, Son valley.

\begin{tabular}{|c|c|c|c|c|c|c|c|c|c|c|}
\hline & \multicolumn{10}{|c|}{ Bijaigarh tuffaceous beds } \\
\hline & BJT-1 & BJT-2 & BJT-3 & BJT-4 & BJT-5 & BJT-6 & BJT-7 & SPC-Tff & NNT-1 & NNT-2 \\
\hline \multicolumn{11}{|c|}{ Major oxides (wt\%) } \\
\hline $\mathrm{SiO}_{2}$ & 67.49 & 64.05 & 66.21 & 66.26 & 66.65 & 65.74 & 69.11 & 64.5 & 70.23 & 69.85 \\
\hline $\mathrm{TiO}_{2}$ & 1.09 & 1.05 & 0.95 & 0.95 & 1.2 & 1.51 & 0.71 & 0.8 & 0.758 & 0.762 \\
\hline $\mathrm{Al}_{2} \mathrm{O}_{3}$ & 20.37 & 23.76 & 21.92 & 22.85 & 22.97 & 20.83 & 16.41 & 19.27 & 17.76 & 18.58 \\
\hline $\mathrm{Fe}_{2} \mathrm{O}_{3}$ & 1.44 & 1.39 & 2.21 & 1.6 & 1.37 & 1.98 & 5.29 & 5.49 & 1.52 & 1.7 \\
\hline $\mathrm{MnO}$ & 0.01 & 0.01 & 0.04 & 0.01 & 0.01 & 0.01 & 0.13 & 0.02 & 0.007 & 0.011 \\
\hline $\mathrm{MgO}$ & 0.84 & 0.85 & 0.98 & 0.81 & 0.82 & 0.75 & 0.9 & 1.57 & 0.71 & 0.84 \\
\hline $\mathrm{CaO}$ & 0.14 & 0.1 & 0.23 & 0.14 & 0.13 & 0.21 & 0.16 & 0.2 & 0.05 & 0.06 \\
\hline $\mathrm{Na}_{2} \mathrm{O}$ & 0.21 & 0.13 & 0.12 & 0.1 & 0.09 & 0.06 & 0.1 & 0.11 & 0.1 & 0.11 \\
\hline $\mathrm{K}_{2} \mathrm{O}$ & 5.71 & 5.61 & 5.42 & 5.38 & 5.47 & 6.35 & 3.55 & 5.11 & 4.21 & 4.47 \\
\hline $\mathrm{P}_{2} \mathrm{O}_{5}$ & 0.05 & 0.06 & 0.05 & 0.05 & 0.05 & 0.06 & 0.07 & 0.04 & 0.03 & 0.04 \\
\hline LOI & 2.51 & 2.64 & 1.98 & 1.65 & 1.55 & 2.59 & 3.96 & 2.96 & 4.07 & 4.27 \\
\hline Total & 99.86 & 99.65 & 100.11 & 99.8 & 100.31 & 100.09 & 100.38 & 100.07 & 99.45 & 100.6 \\
\hline CIA & 75.36 & 78.98 & 77.50 & 78.87 & 78.78 & 74.29 & 79.89 & 76.32 & 76.32 & 76.32 \\
\hline PIA & 97.67 & 98.75 & 97.92 & 98.64 & 98.76 & 98.17 & 98.02 & 97.86 & 98.91 & 98.81 \\
\hline \multicolumn{11}{|c|}{ Trace element (ppm) } \\
\hline $\mathrm{Rb}$ & 258 & 140 & 153 & 267 & 292 & 230 & 176 & 157 & 192 & 223 \\
\hline $\mathrm{Sr}$ & 109 & 63 & 65 & 105 & 114 & 57 & 78 & 60 & 35 & 38 \\
\hline $\mathrm{Ba}$ & 657 & 239 & 387 & 304 & 336 & 257 & 678 & 346 & 385 & 424 \\
\hline Y & 140 & 46 & 36 & 90 & 100 & 73 & 45 & 23 & 36 & 39 \\
\hline $\mathrm{Zr}$ & 1096 & 193 & 1127 & 369 & 384 & 260 & 489 & 173 & 252 & 253 \\
\hline $\mathrm{Hf}$ & 25 & 6 & 28 & 12 & 12 & 9 & 15 & 6 & 6 & 8 \\
\hline $\mathrm{Nb}$ & 25 & 14 & 27 & 26 & 27 & 15 & 16 & 12 & 13 & 15 \\
\hline $\mathrm{Ta}$ & 2 & 1 & 2 & 2 & 2 & 2 & 1 & 1 & 1.4 & 1.5 \\
\hline $\mathrm{Th}$ & 28 & 25 & 29 & 29 & 23 & 18 & 29 & 17 & 21.2 & 22.5 \\
\hline $\mathrm{U}$ & 12 & 6 & 14 & 13 & 13 & 3 & 5 & 4 & 4 & 4.3 \\
\hline $\mathrm{Ni}$ & 48 & 6 & 50 & 22 & 21 & 26 & 25 & 12 & 19 & 21 \\
\hline Co & 2.8 & 1.4 & 3.6 & 4.7 & 6.6 & 5.6 & 8.7 & 4.8 & 4 & 7 \\
\hline $\mathrm{V}$ & 122 & 66 & 146 & 134 & 132 & 99 & 58 & 108 & 87 & 93 \\
\hline $\mathrm{Cr}$ & 132 & 31 & 143 & 119 & 127 & 110 & 111 & 28 & 150 & 120 \\
\hline $\mathrm{Sc}$ & 23 & 15 & 27 & 18 & 24 & 24 & 17 & 22 & 13 & 13 \\
\hline $\mathrm{Pb}$ & 76 & 54 & 77 & 25 & 22 & 20 & 48 & 14 & 18 & 18 \\
\hline \multicolumn{11}{|c|}{ Rare earth elements } \\
\hline $\mathrm{La}$ & 91.45 & 65.28 & 39.61 & 98.45 & 99.16 & 42.45 & 64.40 & 38.71 & 45.5 & 49.5 \\
\hline $\mathrm{Ce}$ & 122.56 & 91.32 & 71.23 & 131.96 & 137.28 & 69.44 & 133.75 & 73.91 & 95.7 & 104 \\
\hline $\operatorname{Pr}$ & 16.49 & 11.52 & 8.92 & 17.62 & 18.51 & 8.43 & 14.58 & 8.42 & 10.1 & 10.9 \\
\hline $\mathrm{Nd}$ & 51.76 & 35.73 & 30.35 & 56.4 & 58.87 & 28.58 & 53.91 & 29.34 & 36.5 & 37.2 \\
\hline $\mathrm{Sm}$ & 8.6 & 5.41 & 5.56 & 9.76 & 10 & 5.24 & 11.05 & 4.95 & 7 & 7.2 \\
\hline $\mathrm{Eu}$ & 1.69 & 1.01 & 0.95 & 2.061 & 1.94 & 1.04 & 1.91 & 0.85 & 1.19 & 1.31 \\
\hline Gd & 8.41 & 5.11 & 3.98 & 10.13 & 10.36 & 4.63 & 8.79 & 3.88 & 6.2 & 6.9 \\
\hline $\mathrm{Tb}$ & 1.71 & 1.04 & 0.77 & 2.14 & 2.31 & 0.87 & 1.47 & 0.66 & 1.1 & 1.1 \\
\hline Dy & 12.01 & 7.1 & 4.13 & 14.27 & 15.44 & 5.27 & 8.29 & 3.97 & 6.8 & 7.4 \\
\hline Ho & 2.6 & 1.59 & 1.12 & 3.24 & 3.42 & 1.18 & 1.64 & 0.86 & 1.4 & 1.4 \\
\hline Er & 7.59 & 4.49 & 3.01 & 9.04 & 9.71 & 3.45 & 4.51 & 2.54 & 4.1 & 4.2 \\
\hline $\operatorname{Tm}$ & 1.32 & 0.74 & 0.532 & 1.56 & 1.7 & 0.61 & 0.76 & 0.43 & 0.6 & 0.61 \\
\hline $\mathrm{Yb}$ & 8.54 & 4.82 & 3.06 & 9.54 & 10.21 & 3.90 & 5.10 & 2.84 & 4.1 & 4.3 \\
\hline $\mathrm{Lu}$ & 1.21 & 0.74 & 0.56 & 1.54 & 1.63 & 0.66 & 0.78 & 0.46 & 0.64 & 0.63 \\
\hline$\sum \mathrm{REE}$ & 335.94 & 235.90 & 173.78 & 367.71 & 380.54 & 175.74 & 310.95 & 171.82 & 220.93 & 236.65 \\
\hline$[\mathrm{La} / \mathrm{Yb}]_{N}$ & 7.7 & 9.7 & 9.30 & 7.4 & 7.0 & 7.8 & 9.1 & 9.8 & 7.96 & 8.3 \\
\hline$[\mathrm{Gd} / \mathrm{Yb}]_{N}$ & 0.81 & 0.88 & 1.08 & 0.88 & 0.84 & 0.98 & 1.43 & 1.13 & 1.3 & 1.3 \\
\hline$[\mathrm{Ce} / \mathrm{Yb}]_{N}$ & 3.99 & 5.26 & 6.47 & 3.84 & 3.73 & 4.94 & 7.28 & 7.23 & 6.5 & 6.7 \\
\hline $\mathrm{Eu} / \mathrm{Eu}^{*}$ & 0.61 & 0.58 & 0.62 & 0.63 & 0.58 & 0.65 & 0.59 & 0.59 & 0.55 & 0.57 \\
\hline
\end{tabular}


Table 2. (Continued.)

\begin{tabular}{|c|c|c|c|c|c|c|c|c|}
\hline & \multicolumn{8}{|c|}{ Bijaigarh siliciclastics } \\
\hline & MR-8 & MAR-4 & MAR-22 & MR-6 & SPC-7 & MAR-25 & SPC-6 & MAR-10 \\
\hline \multicolumn{9}{|c|}{ Major oxides (wt\%) } \\
\hline $\mathrm{SiO}_{2}$ & 74.50 & 74.78 & 72.47 & 72.50 & 72.5 & 78.41 & 81.74 & 81.94 \\
\hline $\mathrm{TiO}_{2}$ & 0.62 & 0.61 & 0.56 & 0.57 & 0.53 & 0.45 & 0.42 & 0.44 \\
\hline $\mathrm{Al}_{2} \mathrm{O}_{3}$ & 12.39 & 12.09 & 13.7 & 14.2 & 13.12 & 10.15 & 9.65 & 8.6 \\
\hline $\mathrm{Fe}_{2} \mathrm{O}_{3}$ & 3.30 & 3.26 & 3.53 & 3.10 & 4.7 & 4.0 & 2.23 & 3.6 \\
\hline $\mathrm{MnO}$ & 0.01 & 0.01 & 0.02 & 0.02 & 0.02 & 0.02 & 0.02 & 0.01 \\
\hline $\mathrm{MgO}$ & 0.9 & 0.7 & 1.2 & 1.50 & 1.24 & 0.91 & 0.92 & 0.41 \\
\hline $\mathrm{CaO}$ & 0.20 & 0.12 & 0.2 & 0.30 & 0.14 & 0.14 & 0.11 & 0.06 \\
\hline $\mathrm{Na}_{2} \mathrm{O}$ & 0.11 & 0.07 & 0.12 & 0.12 & 0.14 & 0.11 & 0.14 & 0.04 \\
\hline $\mathrm{K}_{2} \mathrm{O}$ & 3.40 & 3.39 & 3.78 & 3.50 & 3.63 & 2.47 & 2.72 & 2.22 \\
\hline $\mathrm{P}_{2} \mathrm{O}_{5}$ & 0.04 & 0.04 & 0.06 & 0.05 & 0.07 & 0.03 & 0.02 & 0.06 \\
\hline LOI & 3.6 & 3.6 & 3.93 & 3.82 & 3.99 & 3.56 & 2.28 & 2.72 \\
\hline Total & 99.07 & 98.63 & 99.58 & 99.68 & 100.08 & 100.25 & 100.25 & 100.10 \\
\hline CIA & 75.00 & 75.58 & 75.28 & 76.30 & 75.56 & 77.00 & 74.42 & 77.94 \\
\hline PIA & 96.67 & 97.86 & 96.88 & 96.22 & 97.13 & 96.85 & 96.52 & 98.46 \\
\hline \multicolumn{9}{|c|}{ Trace element (ppm) } \\
\hline $\mathrm{Rb}$ & 155 & 151 & 180 & 169 & 158 & 123 & 115 & 106 \\
\hline $\mathrm{Sr}$ & 55 & 51 & 59 & 65 & 40 & 34 & 26 & 30 \\
\hline $\mathrm{Ba}$ & 350 & 342 & 437 & 435 & 446 & 282 & 301 & 217 \\
\hline $\mathrm{Y}$ & 32 & 31 & 31 & 32 & 32 & 37 & 30 & 21 \\
\hline $\mathrm{Zr}$ & 240 & 231 & 259 & 255 & 180 & 274 & 233 & 244 \\
\hline Hf & 5 & 6 & 9 & 5 & 6 & 11 & 7 & 6 \\
\hline $\mathrm{Nb}$ & 15 & 11 & 15 & 15 & 14 & 12 & 11 & 8 \\
\hline $\mathrm{Ta}$ & 1 & 1 & 2 & 2 & 2 & 2 & 1 & 1 \\
\hline Th & 10 & 14 & 22 & 20 & 19 & 14 & 11 & 12 \\
\hline $\mathrm{U}$ & 5 & 4 & 6 & 7 & 4 & 4 & 5 & 3 \\
\hline $\mathrm{Ni}$ & 19 & 20 & 13 & 16 & 21 & 26 & 10 & 20 \\
\hline $\mathrm{Co}$ & 2 & 3 & nd & 3 & nd & nd & nd & 2.0 \\
\hline $\mathrm{V}$ & nd & 59 & nd & nd & nd & nd & nd & 42 \\
\hline $\mathrm{Cr}$ & 59 & 60 & nd & 59 & nd & nd & nd & 60 \\
\hline $\mathrm{Sc}$ & 9 & 10 & 7 & 9 & 9 & 7 & 7 & 7 \\
\hline $\mathrm{Pb}$ & 8 & 8 & 6 & 9 & 7 & 10 & 8 & 7 \\
\hline \multicolumn{9}{|c|}{ Rare earth elements } \\
\hline $\mathrm{La}$ & 35.80 & 35.60 & 40.43 & 29.50 & 38.48 & 35.07 & 29.58 & 29.70 \\
\hline $\mathrm{Ce}$ & 69.40 & 69.90 & 82.34 & 59.80 & 75.55 & 70.38 & 59.98 & 60.60 \\
\hline $\operatorname{Pr}$ & 7.85 & 7.83 & 8.61 & 6.42 & 8.13 & 8.03 & 6.32 & 6.43 \\
\hline $\mathrm{Nd}$ & 30.10 & 30.20 & 35.52 & 24.30 & 33.11 & 34.01 & 25.78 & 24.10 \\
\hline $\mathrm{Sm}$ & 5.90 & 6.00 & 6.88 & 4.60 & 6.96 & 7.44 & 5.45 & 4.40 \\
\hline $\mathrm{Eu}$ & 1.30 & 1.20 & 1.24 & 0.95 & 1.37 & 1.46 & 1.07 & 0.84 \\
\hline $\mathrm{Gd}$ & 5.60 & 5.50 & 5.35 & 4.10 & 6.00 & 6.43 & 4.43 & 3.90 \\
\hline $\mathrm{Tb}$ & 1.00 & 0.90 & 1.03 & 0.90 & 1.08 & 1.32 & 0.80 & 0.70 \\
\hline Dy & 5.20 & 5.10 & 6.03 & 4.20 & 6.45 & 8.19 & 4.62 & 4.00 \\
\hline Ho & 1.20 & 1.10 & 1.25 & 0.95 & 1.33 & 1.66 & 0.98 & 0.80 \\
\hline Er & 3.40 & 3.30 & 3.91 & 2.80 & 4.07 & 4.93 & 2.99 & 2.50 \\
\hline $\mathrm{Tm}$ & 0.51 & 0.51 & 0.61 & 2.43 & 0.59 & 0.72 & 0.43 & 0.40 \\
\hline $\mathrm{Yb}$ & 3.40 & 3.40 & 3.76 & 0.43 & 3.67 & 4.58 & 2.82 & 2.60 \\
\hline $\mathrm{Lu}$ & 0.53 & 0.52 & 0.59 & 0.43 & 0.61 & 0.75 & 0.47 & 0.40 \\
\hline$\sum \mathrm{REE}$ & 171.19 & 171.06 & 197.55 & 141.81 & 187.39 & 184.99 & 145.72 & 141.37 \\
\hline$[\mathrm{La} / \mathrm{Yb}]_{N}$ & 7.6 & 7.5 & 7.7 & 49.2 & 7.5 & 5.5 & 7.5 & 8.2 \\
\hline$[\mathrm{Gd} / \mathrm{Yb}]_{N}$ & 1.36 & 1.34 & 1.18 & 7.89 & 1.35 & 1.16 & 1.30 & 1.24 \\
\hline$[\mathrm{Ce} / \mathrm{Yb}]_{N}$ & 5.67 & 5.71 & 6.09 & 38.63 & 5.71 & 4.27 & 5.91 & 6.47 \\
\hline $\mathrm{Eu} / \mathrm{Eu}^{*}$ & 0.69 & 0.64 & 0.62 & 0.67 & 0.65 & 0.64 & 0.66 & 0.62 \\
\hline
\end{tabular}



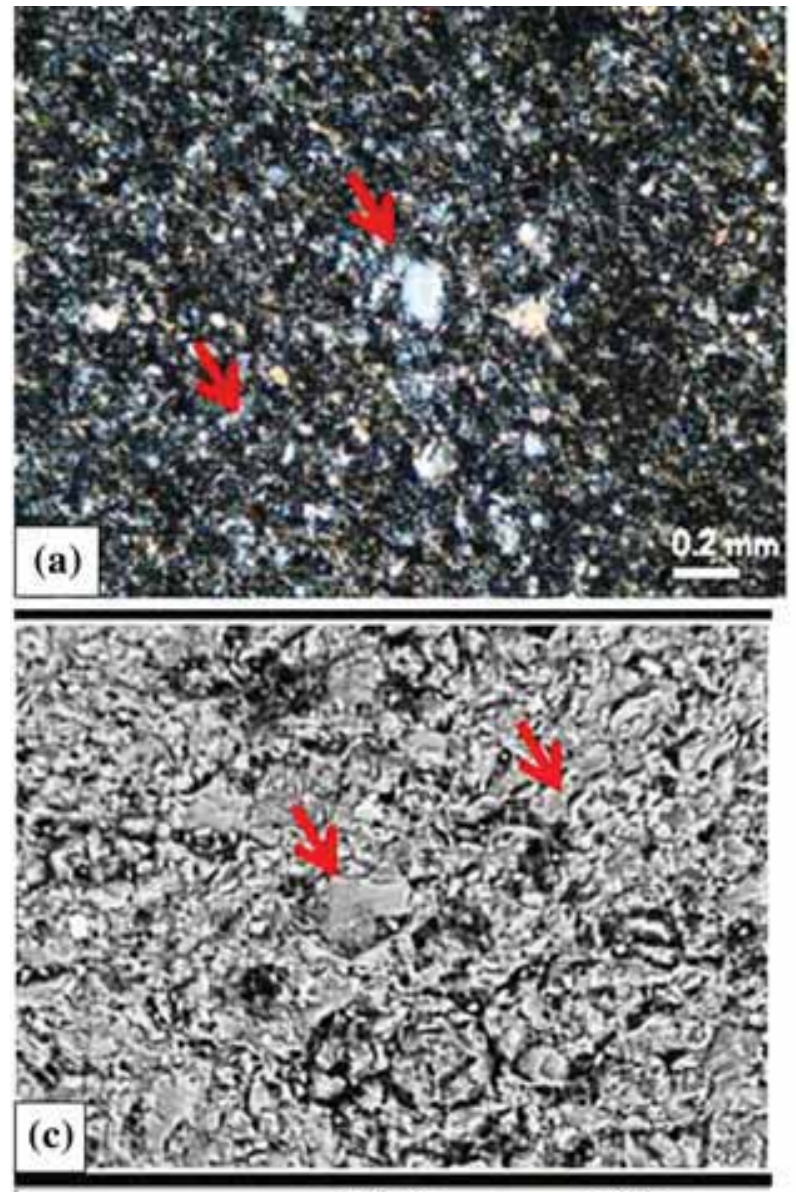

$100 . \mu \mathrm{m}$

BSE Z
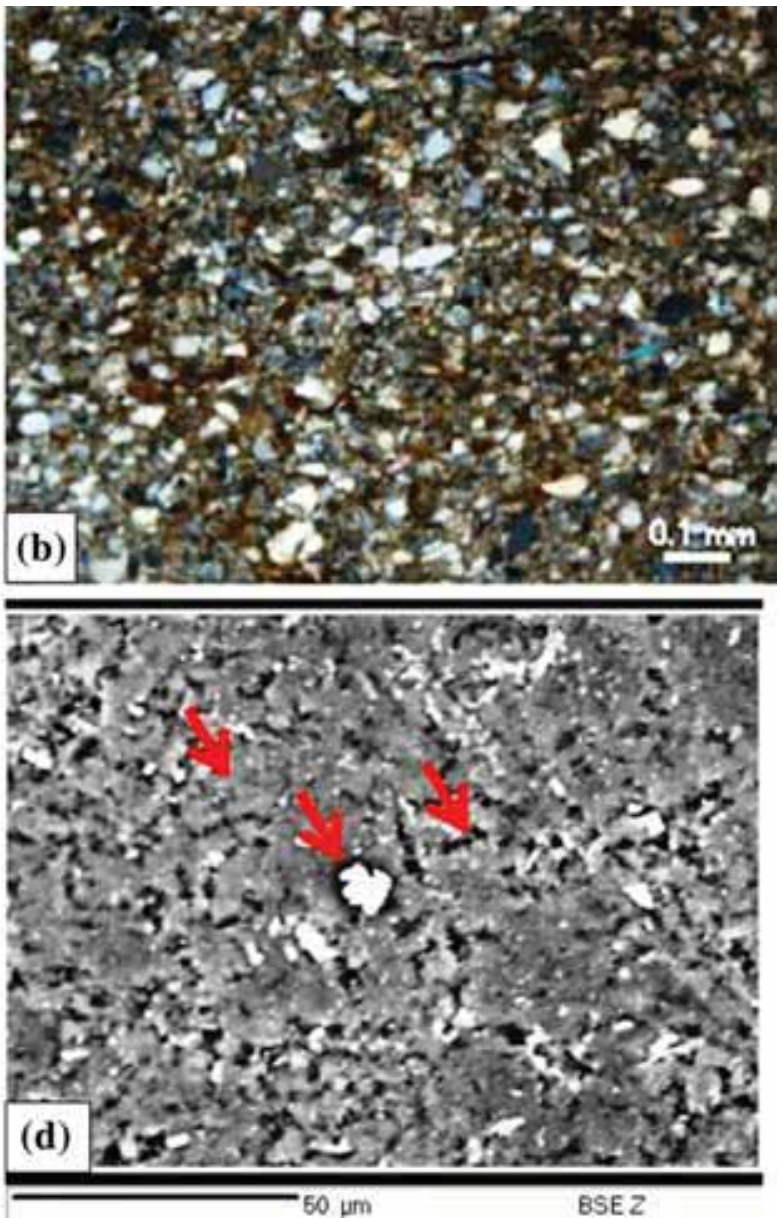

Figure 6. (a) Photomicrograph of tuff showing microphenocryst of bipyramidal quartz in the vitrophyric ground mass. Arrow shows glass shard; (b) fine-grained clastic nature of Bijaigarh shale showing ferruginous sediment; (c) backscattered image of altered cuspate glass shard and fibrous illite; and (d) backscattered image of spiky illite and subrounded rutile.

survived alteration (figure 7). Other minerals identified are muscovite, biotite, altered volcanic glass, muscovite, zircon, rutile, hypersthene and illite (figures 6 and 7 ). The igneous texture observed in the tuff could be easily distinguished from the overlying and underlying sedimentary layers of the Bijaigarh shale, which exhibits a texture, typical of siliciclastics (figure 6b) with quartz as the dominant detrital mineral in addition to subordinate feldspars like orthoclase, plagioclase and microcline. The binding materials comprise clay minerals and ferruginous cements of haematite (figure 6b).

\section{Mineralogy}

XRD analysis for the Bijaigarh tuff and siliciclastics shows that illite is the common clay mineral with subordinate kaolinite and montmorillonite. The fine-grained volcanic ash has altered to fibrous and spiky illite (figure 6c and d). Thus, illite is the dominating clay mineral which is in conformation with the XRD data. About $100 \mathrm{~g}$ of coarsely crushed tuffaceous sample was macerated with conventional techniques using $\mathrm{HCl}, \mathrm{HF}, \mathrm{HNO}_{3}$ and $\mathrm{KOH}$. The slide was prepared using polyvinyl alcohol solution and Canada balsam and studied under the petrological microscope. The angular to subangular zircon (figure 7i), glass shards (figure $7 \mathrm{f}$ ), rutile (figure 7e) and hypersthene (figure $7 \mathrm{~g}$ and $\mathrm{h}$ ) were observed in the mounted section. The altered cuspate glass shard (figure 6c), fibrous and spiky illite and angular rutile (figure 6d) are visible in the backscattered images.

\section{Geochemical results}

\subsection{Major oxides}

Tuffs exhibit $\mathrm{SiO}_{2}$ ranging between 64 and 70.23 wt\% (table 2). $\quad \mathrm{TiO}_{2}$ has concentration 

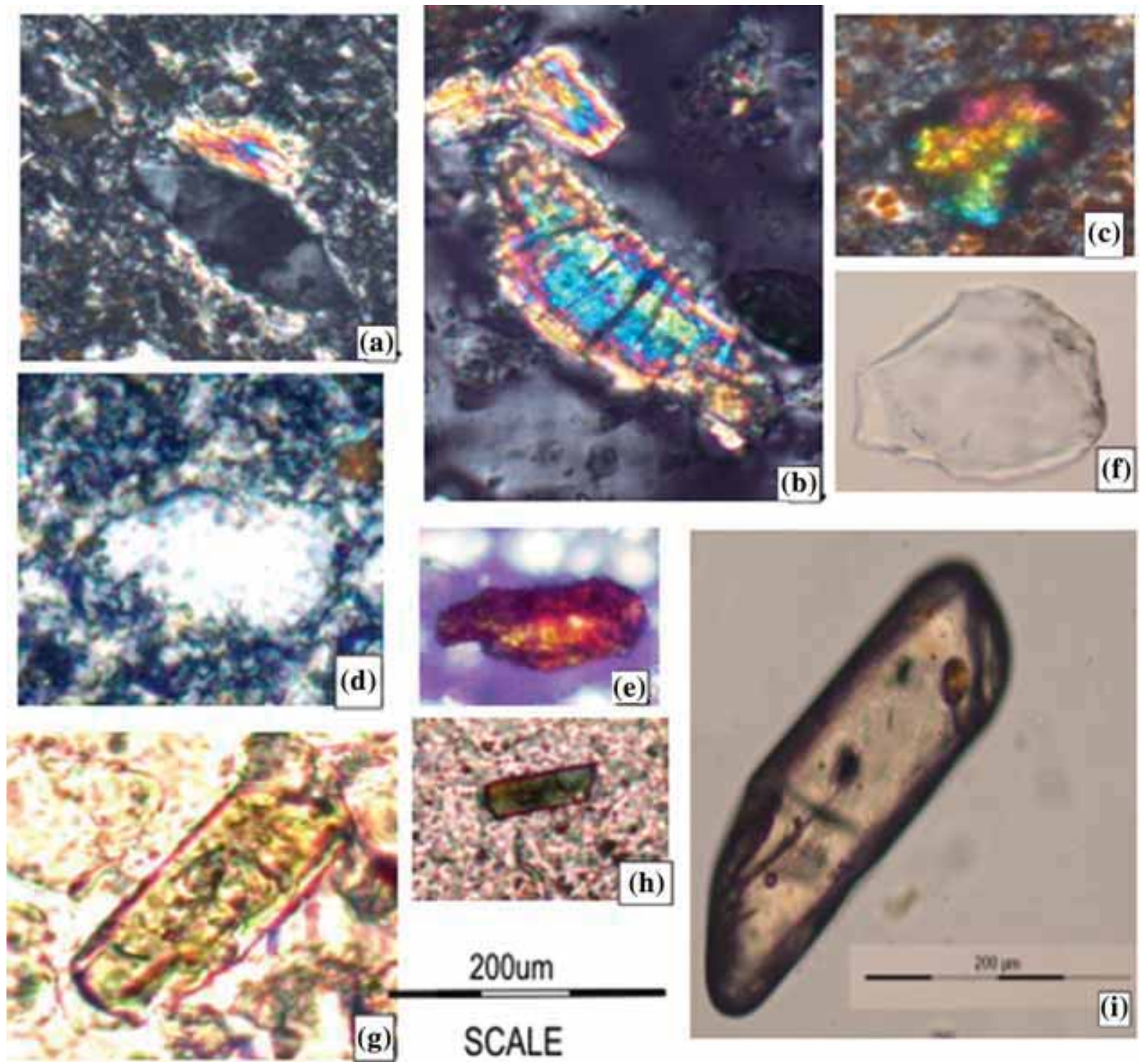

Figure 7. (a) Photomicrograph of welded bipyramidal quartz and muscovite in vitrophyric ground mass; (b) strained muscovite; (c) euhedral zircon showing halo; (d) resorbed and irregular quartz in vitrophyric ground mass; (e) euhedral rutile; (f) cuspate glass shard; (g) and (h) orthopyroxene-hypersthene; (i) subangular euhedral zircon showing zoning and inclusions. Note that photomicrographs (b) and (e)-(i) are from macerated slides.

varying from 0.75 to $1.5 \mathrm{wt} \%$, which may be attributed to the presence of rutile. $\mathrm{Al}_{2} \mathrm{O}_{3}$ shows higher values of about 16.4-23.8 wt\%, probably due to the presence of a good proportion of clay minerals like illite, corroborated by XRD and EPMA data. Elevated values of $\mathrm{Fe}_{2} \mathrm{O}_{3} \%$ in few samples are evident from the reddish colouration in some of the samples (SPC-Tff and BJT-7) due to the oxidation on their surface. Major oxide data of tuffs when compared with that of Bijaigarh siliciclastics reflect significant disparity. Except for $\mathrm{SiO}_{2}$, the tuffs are enriched with $\mathrm{TiO}_{2}, \mathrm{Al}_{2} \mathrm{O}_{3}$ and $\mathrm{K}_{2} \mathrm{O}$ as compared to the latter (table 2).

In all the bivariate scatter plots, using $\mathrm{Al}_{2} \mathrm{O}_{3}$ as the index of differentiation, the tuff samples cluster quite distinctly in a separate field from Bijaigarh siliciclastics (figure 8). The major oxide data of Bijaigarh tuff have also been compared with the tuffaceous beds associated with different Proterozoic basins, i.e., Singhora (Das et al. 2009), Sukhda tuff, Indravati tuff and Dhamda tuff (Bickford et al. 2014). In all the plots, i.e., $\mathrm{Al}_{2} \mathrm{O}_{3}$ vs. $\mathrm{SiO}_{2}$, $\mathrm{MgO}, \mathrm{TiO}_{2}, \mathrm{CaO}, \mathrm{Fe}_{2} \mathrm{O}_{3}(\mathrm{~T}), \mathrm{P}_{2} \mathrm{O}_{5}, \mathrm{~K}_{2} \mathrm{O}$ and REE(T) Bijaigarh tuff samples fall distinctly into separate fields as compared to other tuff samples. The $\mathrm{Al}_{2} \mathrm{O}_{3}$ vs. the $\mathrm{SiO}_{2}$ plot exhibits that all the five tuffs (Bijaigarh, Singhora, Sukhda, Indravati and Dhamda) have varying silica percentage. The general scattering of samples is clearly visible along $\mathrm{Al}_{2} \mathrm{O}_{3}$, i.e., the $x$-axis. This can be attributed to 

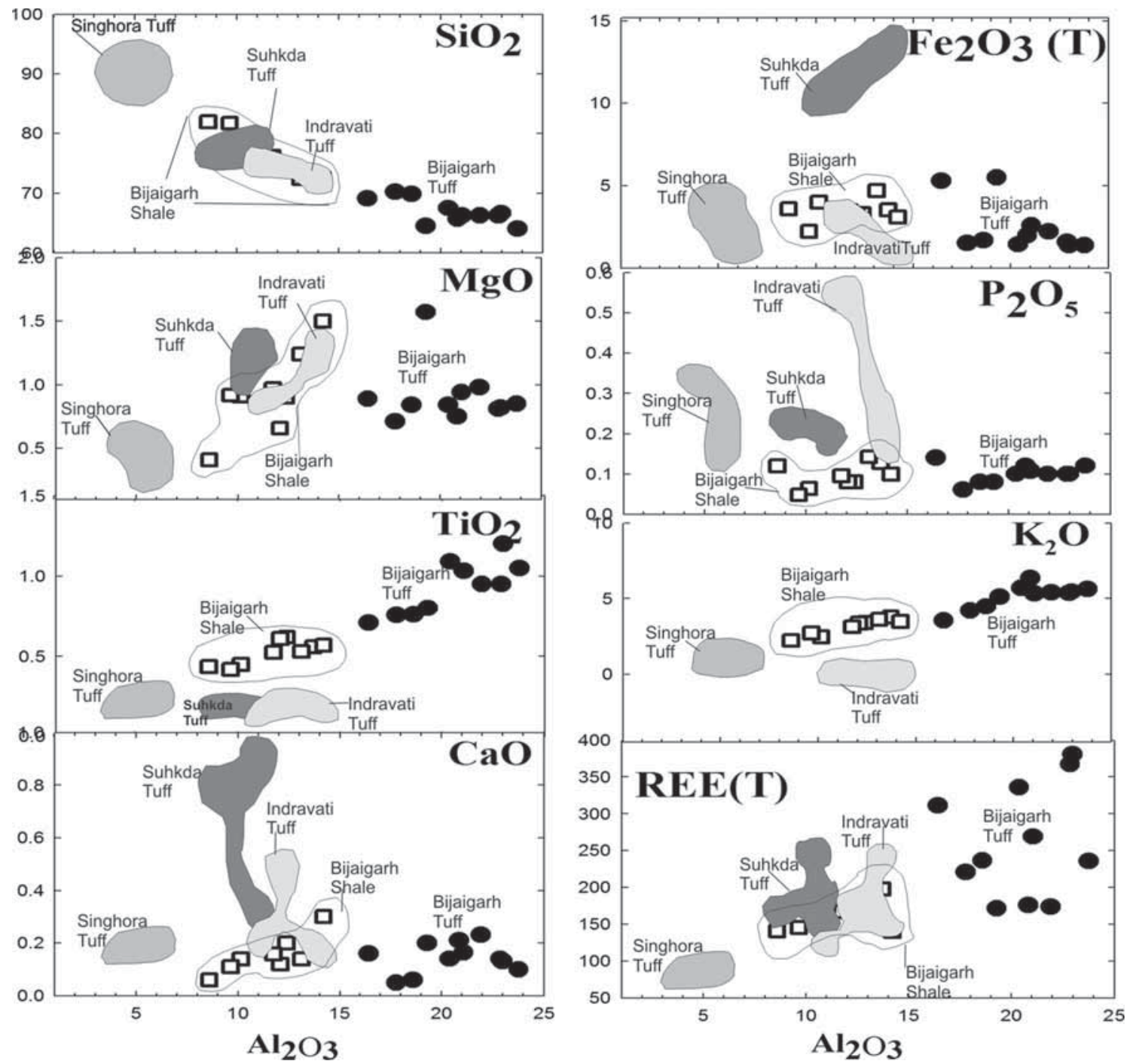

Figure 8. Bivariate plots for major oxides (in wt\%) using $\mathrm{Al}_{2} \mathrm{O}_{3}$ as the index of differentiation, showing the clustering of tuff and Bijaigarh shale. Data sources for Singhora tuff, Sukhda tuff, Indravati tuff and Dhamda tuff are mentioned in the text.

varying degrees of alteration of feldspars to clay minerals. The $\mathrm{Al}_{2} \mathrm{O}_{3}$ vs. the $\mathrm{K}_{2} \mathrm{O}$ plot corroborates this, wherein it is evident that the Bijaigarh tuff has undergone the highest degree of alteration to clay minerals, i.e., illite as evident from mineralogical data. The $\mathrm{Al}_{2} \mathrm{O}_{3}$ vs. the $\mathrm{TiO}_{2}$ plot exhibits that the Bijaigarh tuff is enriched with $\mathrm{TiO}_{2}$ wt\% which is indicated by the presence of rutile in the thin section study. Thus, the major oxide data are suggestive of the marked similarity in the geochemical characters of the Bijaigarh tuff as compared to other tuffs taking into consideration the general scattering of samples along $\mathrm{Al}_{2} \mathrm{O}_{3}$, i.e., the $x$-axis. Interestingly, in all the bivariate plots (figure 8), the distinctness in the siliciclastic nature of the Bijaigarh shale in comparison with the Bijaigarh tuff is reflected. This is also corroborated by the higher $\mathrm{SiO}_{2} / \mathrm{Al}_{2} \mathrm{O}_{3}$ ratio (5-9.5) in comparison with that of the Bijaigarh tuff, ranging from 2.7 to 4.2. The $\mathrm{SiO}_{2}$ vs. the $\mathrm{SiO}_{2} / \mathrm{Al}_{2} \mathrm{O}_{3}$ ratio diagram shows the scattering of samples from Bijaigarh shale in contrast to tuff samples which exhibits close clustering (figure 9). $\mathrm{SiO}_{2} / \mathrm{Al}_{2} \mathrm{O}_{3}$ values for Bijaigarh siliciclastics show a gradual increase during weathering, transport and recycling, due to the increase of quartz in the modal framework at the expense of less-resistant components (Gallala et al. 2009). The $\mathrm{SiO}_{2} / \mathrm{Al}_{2} \mathrm{O}_{3}$ ratio is often used as a grain-size indicator (Dypvik 1979). In contrast, both the tuff and associated siliciclastics exhibit similar $\mathrm{K}_{2} \mathrm{O} / \mathrm{Al}_{2} \mathrm{O}_{3}(0.2-0.3), \quad \mathrm{Na}_{2} \mathrm{O} / \mathrm{K}_{2} \mathrm{O}$ (0.02$0.05)$ and $\mathrm{Al}_{2} \mathrm{O}_{3} / \mathrm{TiO}_{2}(18-25)$ ratios. The unique similarity in these ratios, in spite of the differences in the elemental concentration, could be possibly due to the exposure to similar post-depositional processes. 


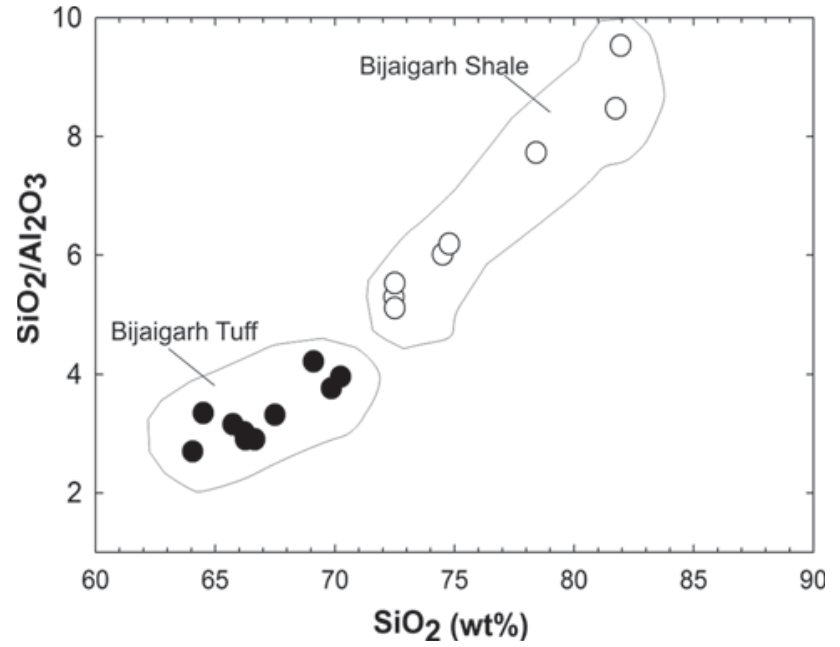

Figure 9. $\mathrm{SiO}_{2}$ vs. $\mathrm{SiO}_{2} / \mathrm{Al}_{2} \mathrm{O}_{3}$ plot to decipher between sedimentary and igneous parentage.

\subsection{Trace elements}

Higher $\mathrm{Rb}$ concentration and their positive correlation with $\mathrm{K}_{2} \mathrm{O}$ and $\mathrm{Al}_{2} \mathrm{O}_{3}$ could be attributed to the presence of clay minerals, i.e., illite as evident from mineralogical and major oxide data. $\mathrm{Zr}$ values for tuff are higher (193-1126 ppm) as compared to Bijaigarh siliciclastics (180-260 ppm) due to the presence of zircon in the former, corroborated by petrographic data and also reflected by substantially higher $\mathrm{Th}, \mathrm{U}$ and $\mathrm{Yb}$ values. Trace element data of tuff beds when compared with that of Bijaigarh siliciclastics show ubiquitously higher concentrations of LILE, HFSE and heavy metals (table 2). The $\mathrm{Zr} / \mathrm{Sc}$ vs. the Th/Sc plot (McLennan et al. 1993) exhibits the clustering of Bijaigarh siliciclastics and tuffs from other Proterozoic basins separately (figure 10). The $\mathrm{Th} / \mathrm{Sc}$ ratio is a pointer of the fractionation of the magmatic detritus and does not vary much in the sediment recycling. In contrast, the $\mathrm{Zr} / \mathrm{Sc}$ ratio will increase significantly during sediment recycling with zircon enrichment/addition and can be considered as a useful indicator of heavy mineral concentration and recycling (McLennan et al. 1993). However, Bijaigarh tuffaceous samples when compared to Bijaigarh siliciclastics cluster separately. Overall, ubiquitously, $\mathrm{Zr}$ addition is evident in all the tuff samples perhaps indicative of the recycling process during deposition. Similarly, the $\mathrm{Zr} / \mathrm{Sm}$ vs. the $\mathrm{Nb} / \mathrm{Ta}$ (Foley et al. 2002) plot exhibits that the Bijaigarh tuff samples plot in the Archaean tonalite-trondhjemite-granodiorite (TTG) field is quite comparable to other tuffs, i.e., Sukhda,

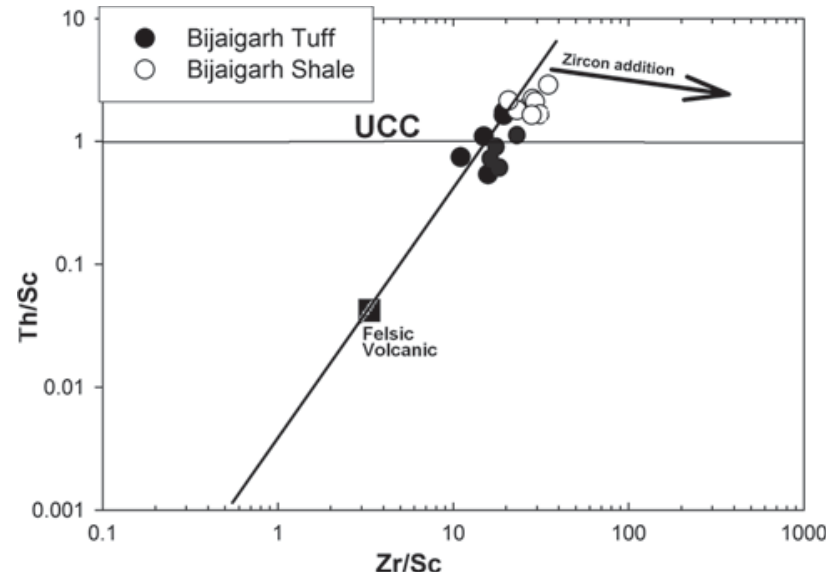

Figure 10. Th/Sc-Zr/Sc diagram (McLennan et al. 1993) shows the Bijaigarh siliciclastics and tuff cluster in separate fields. Values of FV: felsic volcanic is after Condie (1993) and UCC: Upper Continental Crust after Taylor and McLennan (1985).

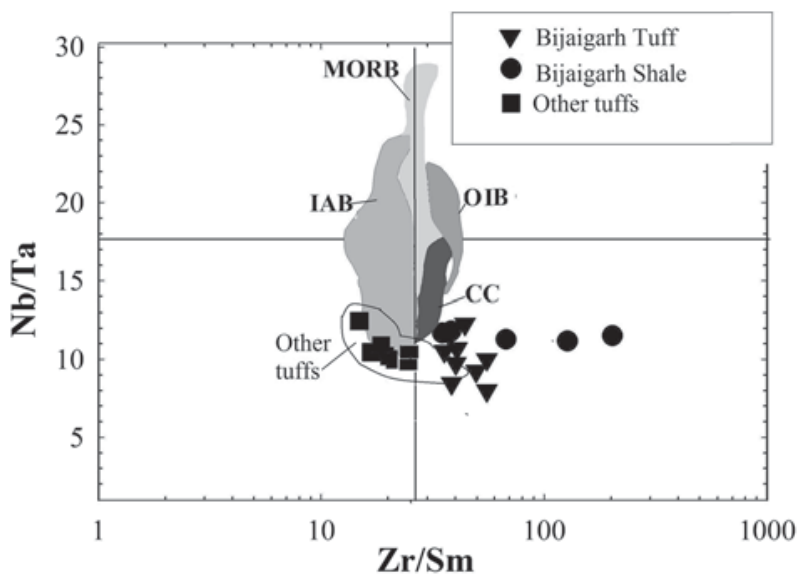

Figure 11. Zr/Sm vs. Nb/Ta plot (Foley et al. 2002) shows that Bijaigarh tuff and other basinal tuffs fall in the Archaean TTG field.

Dhamda and Indravati (figure 11). This indicates the similar tectonic setting of the source to tuffs.

\subsection{Rare earth elements}

$\sum R E E$ of Bijaigarh tuff range from 171 to $380 \mathrm{ppm}$ which are higher as compared to Bijaigarh siliciclastics $167-197 \mathrm{ppm}$ (table 2). The tuffs are also enriched in LREE (236 ppm) and HREE (32 ppm) as compared to the siliciclastics with 146 and 20 ppm, respectively. Tuffs exhibit a well-fractionated pattern with $[\mathrm{La} / \mathrm{Yb}]_{N}=8.4$, nearly flat $[\mathrm{Gd} /$ $\mathrm{Yb}]_{N}=1.06$ and well developed $\mathrm{Eu} / \mathrm{Eu}^{*}=0.59$. These characteristics indicate their derivation from a felsic source and the negative Eu anomaly is regarded as an evidence of a differentiated source, similar to granite (Taylor and McLennan 1985; 
McLennan 1989). Similar to major oxides and trace elements, the chondrite normalised REE plot exhibits distinct abundances and pattern for the Bijaigarh tuff and the associated siliciclastics (figure 12a). A similar behaviour is reflected in the PAAS normalised REE plots (figure 12b). In both the plots, the tuff samples indicate the enrichment of REE as compared to siliciclastics. The PAAS normalised pattern for the Bijaigarh tuff when compared to other tuffs (Singhora, Sukhda, Indravati and Dhamda) exhibits an overlap in REEs, viz., $\mathrm{Pr}, \mathrm{Nd}, \mathrm{Sm}, \mathrm{Eu}, \mathrm{Gd}, \mathrm{Tb}$ and Er pointing towards comparable geochemical characteristics of the former to the latter (figure 13). The chondrite normalised REE patterns of the Bijaigarh tuff were compared with other tuffs (figure 13), exhibit overall highly fractionated REE patterns and a strong negative Eu anomaly. Indravati, Sukhda and Dhamda tuffs exhibit overall highly fractionated REE patterns with $[\mathrm{La} / \mathrm{Yb}]_{N}=39.2,64.2,70.7$ and
$[\mathrm{Gd} / \mathrm{Yb}]_{N}=7.8,11,13.2$, respectively, in comparison with Bijaigarh tuff with $[\mathrm{La} / \mathrm{Yb}]_{N}=8.4,[\mathrm{Gd} /$ $\mathrm{Yb}]=1.06$ and $\mathrm{Eu}$ anomaly $=0.59$. Indravati, Sukhda and Dhamda tuffs exhibit a strong Eu anomaly ranging from 0.3 to 5.3. The Singhora tuff is quite comparable to the Bijaigarh tuff in terms of overall REE fractionation with $[\mathrm{La} / \mathrm{Yb}]_{N}=8.7$ and $[\mathrm{Gd} / \mathrm{Yb}]_{N}=1.5$ and $\mathrm{Eu} / \mathrm{Eu}^{*}-0.6$. The overall enrichment of HREEs is observed in the Bijaigarh tuff in comparison with tuffs from other Proterozoic basins (Singhora, Sukhda, Dhamda and Indravati). This is indicated by a higher abundance of $\mathrm{Zr}$ (173-1096 ppm) in the Bijaigarh tuff in comparison with tuffs (59-230 ppm) from other Proterozoic basins.

The multielement patterns of Bijaigarh tuff are compared to Singhora, Sukhda, Dhamda and Indravati tuffs (figure 14). The incompatible elements $\mathrm{Zr}, \mathrm{Hf}, \mathrm{Sr}, \mathrm{Ti}, \mathrm{Ce}, \mathrm{Tb}, \mathrm{Y}, \mathrm{Tm}$ and $\mathrm{Yb}$ are enriched in the Bijaigarh tuff in comparison with
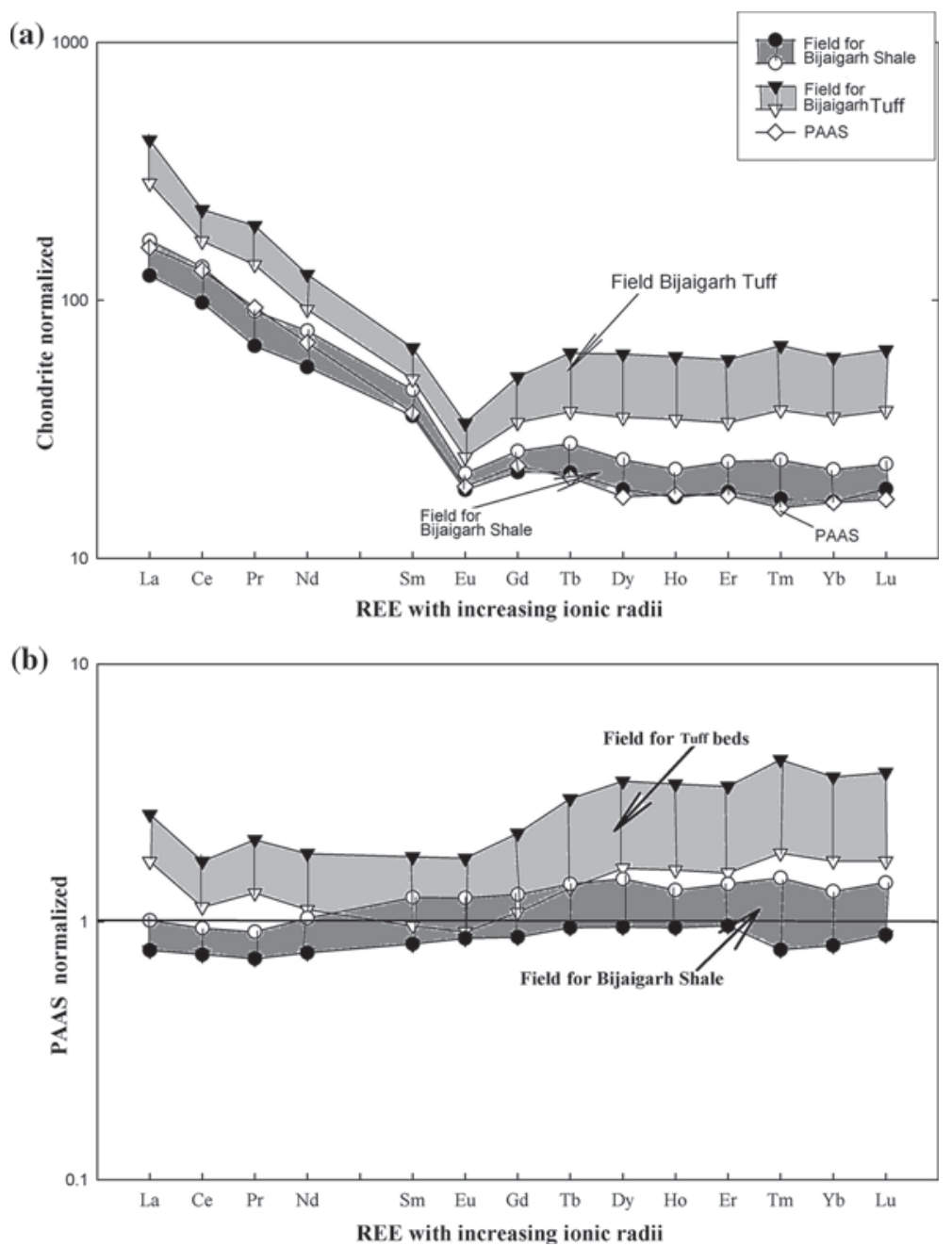

Figure 12. (a) Average chondrite normalised patterns of Bijaigarh tuff and Bijaigarh shale; (b) PAAS normalised patterns showing a range of Bijaigarh tuff, other basinal tuffs and Bijaigarh shale. Values of PAAS taken from Condie (1993). 

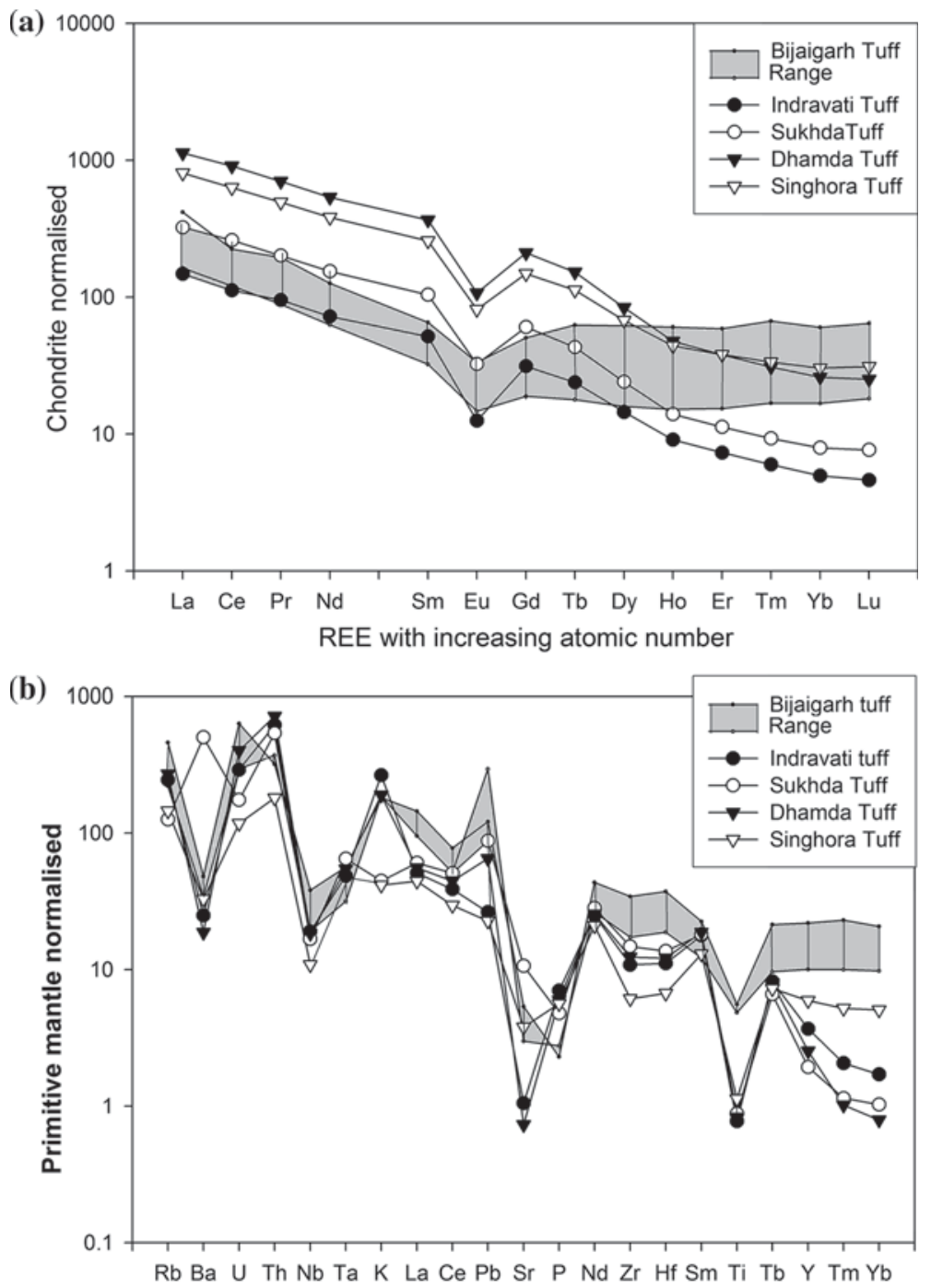

Trace elements with increasing compatibility

Figure 13. Average chondrite normalised pattern of Bijaigarh tuff and its comparison with tuffs from other basins mentioned in the text.

these tuffs, while LILE (Rb, Ba, U, Th and K) and ( $\mathrm{Nb}$ and $\mathrm{Ta}$ ) of the Bijaigarh tuff are comparable to other tuffs (figure 14).

\section{Interpretation and discussion}

The field observations (figures 4, 5a and b), petrological (figures 6 and 7) and mineralogical data support the igneous parentage of the tuffaceous beds sandwiched within the Bijaigarh shale. The differences in the geochemical characters of the Bijaigarh tuff and shale are corroborated by the bivariate diagrams (figure 8), incompatible elemental ratio plots (figures 9 and 10), chondrite (figure 12a) and PAAS normalised diagrams (figure 12b). In all the discrimination plots, the
Bijaigarh tuff samples cluster separately when compared to the associated Bijaigarh shale/siliciclastics signifying their igneous parentage. Bijaigarh tuff/ash beds bear their testimony to the magmatic origin of felsic nature.

\subsection{Classification and tectonic setting}

Since the tuffaceous beds have undergone extensive alteration to clay minerals as evident from their petrography and major oxides, trace elements were used to infer their nature and tectonic setting. When plotted in the $\mathrm{Nb} / \mathrm{Y}$ vs. $\mathrm{Zr} / \mathrm{TiO}_{2} * 0.0001$ classification plot, Winchester and Floyd (1976) point to rhyolitic to rhyodacite affinity (figure 15) which is in conformation with the tuffs from other 


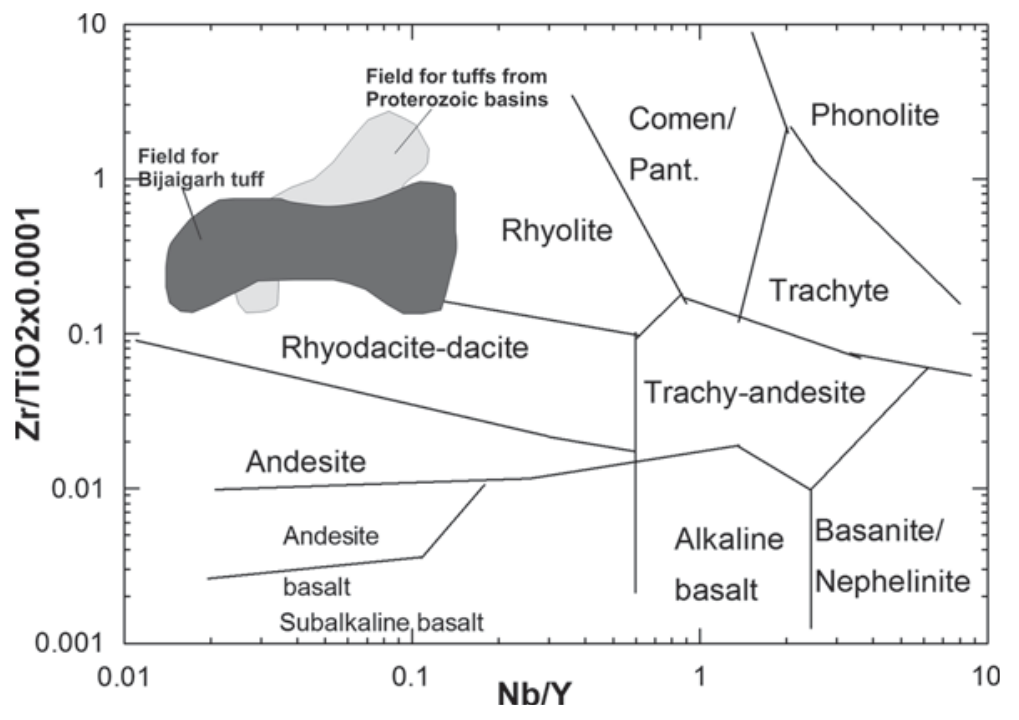

Figure 14. Primitive mantle normalised (Sun and McDonough 1989) plot of trace elements of average Bijaigarh tuff and its comparison with Bijaigarh shale and Singhora tuff. Data sources for Singhora tuff, Sukhda tuff, Dhamda tuff and Indravati tuff are mentioned in the text.

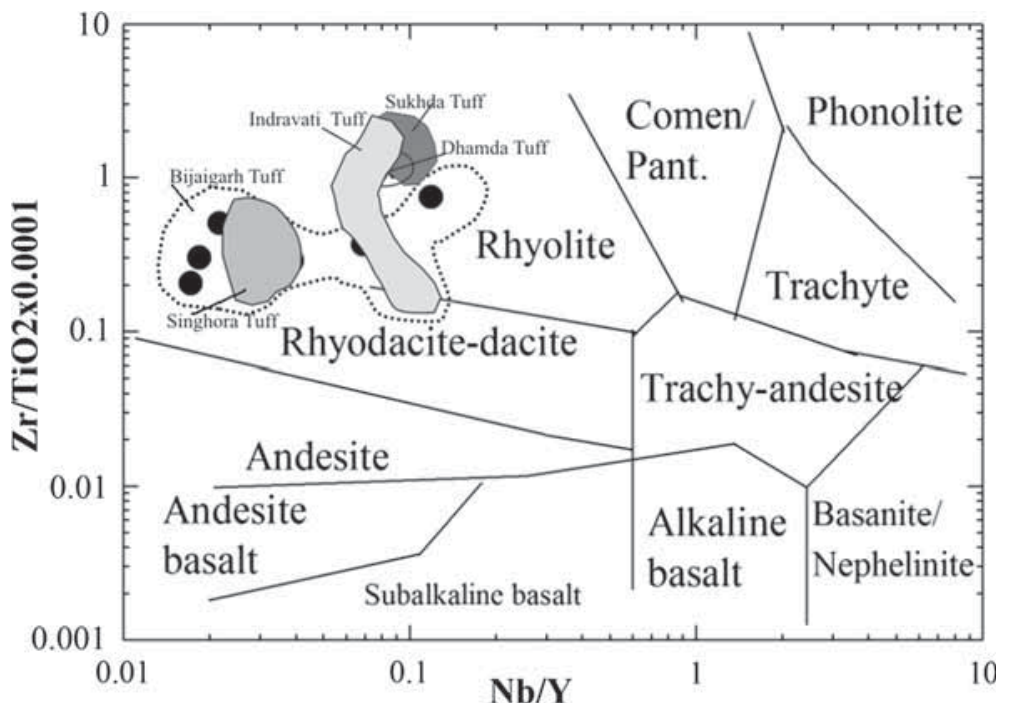

Figure 15. $\mathrm{Zr} / \mathrm{TiO}_{2} \mathrm{X} 0.0001$ vs. Nb/Y plot shows the composition of Bijaigarh tuff as rhyolitic to rhydacitic. Various fields are after Winchester and Floyd (1976). Data sources for Singhora tuff, Sukhda tuff and Indravati tuff are mentioned in the text.

Proterozoic basins like Singhora, Sukhda, Indravati and Dhamda. Tectonic discrimination diagrams using $\mathrm{Y}+\mathrm{Nb}$ vs. $\mathrm{Rb}$ (figure 16a) and $\mathrm{Yb}$ vs. $\mathrm{Ta}$ plots (figure 16b) show that the samples from the tuffaceous beds fall in the within-plate granite (WPG) field indicating passive margin setting. The tuff samples from Singhora (Das et al. 2009), Sukhda and Dhamda tuffs (Bickford et al. 2014) and the Indravati basin (Bickford et al. 2014) show quite similar tectonic affinity when compared with Bijaigarh tuff. The plots (figure 16a and b) show clustering and a partial overlapping of Bijaigarh tuff samples with other basinal tuff in the WPG field. This is in conformation with the $\mathrm{Zr} / \mathrm{Sm} v s$. $\mathrm{Nb} / \mathrm{Ta}$ (Foley et al. 2002) plot (figure 11) which exhibits TTG source for all tuffs.

\subsection{Comparison of Bijaigarh tuff with tuffs from other Proterozoic basins}

Bijaigarh tuff and the four other tuffs are compositionally similar in terms of petrography and mineralogy and their geochemical signatures are also quite comparable. This has been validated with various plots. Bijaigarh tuff similar to other tuffs exhibits rhyolitic to rhyodacitic affinity. The 
(a)

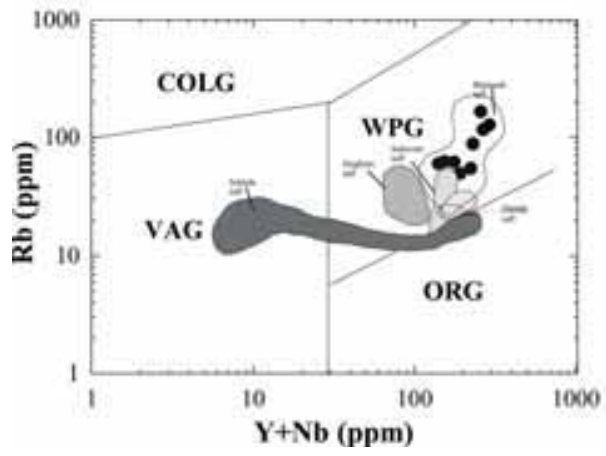

(b)

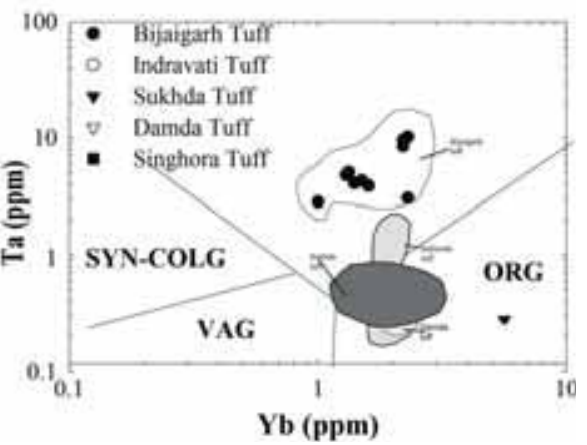

Figure 16. (a) Y + Nb vs. Rb, (b) Ta vs. Yb discrimination diagrams (Pearce et al. 1984) to determine the tectonic setting for tuffaceous beds/ash associated with Bijaigarh shale of Kaimur group. VAG: volcanic arc granite; ORG: ocean-ridge granite; Syn-COLL: syncollisional granite; and WPG: within-plate granite. Data sources for Singhora tuff, Dhamda tuff, Sukhda tuff, Indravati tuff are mentioned in the text.

bivariate plots with $\mathrm{Al}_{2} \mathrm{O}_{3}$ as the differentiation index (figure 8) and various discrimination plots, the $\mathrm{Zr} / \mathrm{Sc}$ vs. Th/Sc plot (figure 10; McLennan et al. 1993), $\mathrm{Zr} / \mathrm{Sm}$ vs. Nb/Ta plot (Foley et al. 2002) and the $\mathrm{Y}+\mathrm{Nb}$ vs. Rb plot (figure 16a and b; Pearce et al. 1984) clearly indicate the comparable geochemical behaviour of the Bijaigarh tuff to other basinal tuffs such as Sukhda, Singhora, Dhamda and Indravati. Chondrite normalised REE patterns also corroborate this (figures 12a and 13). This is supported by the multielement diagram (figure 14) which indicates the comparable behaviour of LILE, Nb and Ta in the Bijaigarh tuff. However, the REE pattern of the Singhora tuff is quite similar to that of the Bijaigarh tuff.

\subsection{Post-depositional K-metasomatism}

Glassy rhyolitic volcanic ash beds are highly susceptible to alteration and the rapid erosion of volcanic rocks and diagenetic alteration of volcanic fragments into clay is a common phenomenon (Huff et al. 1996). Fine-grained volcanic ash also alters to clay minerals very rapidly (GarcíaRomero et al. 2005). Volcanic glass begins to convert to clay minerals almost immediately upon its formation (Fiore 1993) and is known to be the parent material for smectite. The recognition of these materials is the easiest in geologically younger deposits where smectite is a major constituent. Weaver and Beck (1977) indicate that the relative abundance of various clay minerals is a function of geologic age. But with time and deep burial, smectite undergoes a transition to more illite-rich deposits. Thus, the volcanogenic nature of the primary constituents becomes more difficult to distinguish from detrital clays (Nadeau and Reynolds 1981). In such cases, the recognition of the primary magmatic texture can provide clues to their volcanic origin.

In the A-CN-K plot proposed by Nesbitt and Young (1984), the tuff beds and Bijaigarh siliciclastics cluster near illite on the A-K tie line (Mishra and Sen 2012). A higher degree of chemical weathering and plagioclase alteration can be inferred from enhanced CIA (75-80) and PIA (97-98) values. The glass shards, feldspars and micaceous minerals in the tuff samples have possibly been altered to illite (evident from the XRD analysis). However, a petrographic study shows that primary igneous texture has been retained in the tuff. Their mineralogical data indicate strong evidences for illitisation. The feldspars probably have undergone illitisation (figure $6 \mathrm{c}$ and $\mathrm{d}$ ). Potassium metasomatism involves the conversion of kaolin (alteration product of volcanic ash) to illite by reaction with $\mathrm{K}^{+}$bearing pore waters. This can also occur by the replacement of plagioclase by potassium feldspar (Fedo et al. 1995). The possibility of post-depositional high degree $\mathrm{K}$-metasomatism in the ash beds similar to its counterpart, i.e., Bijaigarh shale (Mishra and Sen 2012) cannot be denied. This is also supported by the similarity in $\mathrm{K}_{2} \mathrm{O} / \mathrm{Al}_{2} \mathrm{O}_{3}, \quad \mathrm{Na}_{2} \mathrm{O} / \mathrm{K}_{2} \mathrm{O}$ and $\mathrm{Al}_{2} \mathrm{O}_{3} / \mathrm{TiO}_{2}$ ratios in the tuff and siliciclastics.

\subsection{Intrabasinal vs. extrabasinal input of volcanic ash}

The recognition of subaerial or subaqueous depositional environment for a pyroclastic flow product is difficult in the rock record, and often 
leads to controversy. A subaqueous flow may either be fed directly from subaqueous eruption or from a subaerial eruption that is reworked and deposited under subaqueous conditions (Fisher and Schmincke 1984; Cas and Wright 1991; McPhie et al. 1993). The reworking and transport of pyroclastic flows in subaqueous conditions rather than under subaerial conditions is inferred from features such as the shapes of glass shards, interbedding with non-volcanic sequence, good sorting producing crystal-rich and glass-rich layers, absence of any volcanic vent in the form of dyke or plug nearby (Wright and Mutti 1981; Cousineau 1994). The presence of dominant cuspate shards and angular to subangular fragments indicates subaerial eruption (Cashman and Fiske 1991). The minerals in the Bijaigarh tuffaceous beds exhibit typical cuspate-shaped glass shards, which are devitrified. The angular to subangular glass shards, muscovite, quartz and accessory minerals like rutile and zircon indicate subaerial eruption rather than phreatomagmatic eruption (Heiken and Wohletz 1985; Nemeth 2010). The absence of pumice and welding texture also negates the possibility of subaqueous eruption. The petrographic and mineralogical data of Bijaigarh tuff show the presence of a vitrophyric texture with bipyramidal quartz and resorbed feldspar, angular to subangular zircon, rutile, quartz, glass shards. The absence of pumice and welding texture is also observed in these tuffs. The Son valley sector is devoid of any of evidences of intrabasinal volcanism during the deposition of Upper Kaimur suggest that these tuff beds are possibly the result of the extrabasinal volcanism. It has been observed that the rhyolitic magmas are ejected in violent and explosive eruptions. Their ashes travel great distances, sometimes thousands of kilometres before falling (Coutinho and Hachiro 2005; Self 2006; Poma et al. 2009).

Chanda and Bhattacharya (1982) advocated tectonic activity preceded the deposition of Kaimur which is evidenced by frequent changes in its sedimentation pattern. The depositional environment of Kaimur group sediment ranges from a tidal flat environment to a storm-influenced inner shelf setting to a lagoonal environment to nearshore braidplain delta in the lower part to the braidplain aeolian sandsheet as we move upwards during the deposition of Dhandraul Quartzite (Chakraborty and Bose 1990; Bhattacharya and Morad 1993; Chakraborty 2006). Thus, Chanda and Bhattacharya (1982) suggested the evidences of the omnipresent northwesterly wind drift current direction during the deposition of the Upper Kaimur. This suggests that fine-grained volcanic ashes plausibly had their source towards the south or the south-east. For this reason we have compared Singhora tuff (Das et al. 2009), Sukhda tuff and Dhamda tuff (Bickford et al. 2014) from the Chhattisgarh basin, which is the second largest of the Proterozoic basins of peninsular India and the Indravati basin (Bickford et al. 2014). The fine-grained sediments or volcanic ashes possibly were transported and trapped with depositing Bijaigarh sediments in the lagoonal environment. The geochemical data also suggest that tuffs associated with Bijaigarh siliciclastics also show close affinity to the within-plate type of tectonic setting in the passive margin which supports this deduction. Bose et al. (2001), Paikaray et al. (2005) and Sur et al. (2006) considered the offshore origin of Bijaigarh shale. Singh (1980) considered them to have been deposited in a lagoonal euxinic atmosphere. The atmosphere becomes anoxic due to the influx of greenhouse gases like $\mathrm{CO}_{2}$ and water vapour resulting from large-scale continental volcanism (Young 1995; Tajika 2003; Kah and Riding 2007). This is evident from the contemporaneity in the occurrence of tuffaceous beds in nearly all the Proterozoic sedimentary successions in the Indian subcontinent.

\subsection{Relation between volcanic detritus and microbiota}

The volcanic ash falls provide a geochemically favourable substrate that is both nutrient-rich and has high water retention, making them good hosts for microbiota (Parnell and Foster 2012). The value of volcanic ash to plant life is implied by the fact that the most densely populated area of the world in Indonesia, and other high-density populations in Africa, are on young volcanic ash with very high soil productivity (Shoji et al. 1993). Kumar (2001), Schieber (2004), Sarkar et al. (2006) and Sur et al. (2006) suggest that microbial mats colonised in shallow water during the deposition of Bijaigarh shale. Life flourished possibly due to the addition of volcanic ashes with Bijaigarh siliciclastics. This plausibly bears testimony to the effect of extrabasinal volcanism during the deposition of tuff associated with the Bijaigarh shale.

\subsection{Regional and global significance of Bijaigarh tuff}

The Proterozoic basins have been marked by tuffs at different stratigraphic levels. Bickford et al. 
(2011a, b, 2014) have interpreted that Sukhda and Dhamda tuffs of the Chhattisgarh basin and tuffs from the Indravati basin were the result of $1000 \mathrm{Ma}$ rhyolite 'flare-up' in Peninsular India. This was the consequence of the accretion of parts of east Antarctica, specifically the Rayner terrane (Veevers and Saeed 2009) with the Indian craton during the assembly of Rodinia. This accretion is recorded in the high-grade Eastern Ghats mobile belt (EGMB) in peninsular India (Rogers and Santosh 2004; Rino et al. 2008). This tectonothermal event is reported to be correlatable with the 'Grenville Orogeny' and is placed at $\sim 1100$ Ma by Roy et al. (2006), at $\sim 1000 \mathrm{Ma}$ by Bhowmik et al. (2010) which acted as the basement ridge between Rajasthan and the Son valley sector (Sarkar et al. 1995; Prasad and Rao 2006). In the absence of evidence of intrabasinal volcanism during the deposition of Bijaigarh shale, frequent changes in the sedimentation pattern of Kaimur and evidences of the omnipresent north-westerly wind drift current direction during the deposition of Upper Kaimur (Chanda and Bhattacharya 1982), this hypothesis favours and supports the extrabasinal and subaerial origin of Bijaigarh tuff of rhyolitic and rhyodacitic nature.

\subsection{Stratigraphic marker horizon for Kaimur group sedimentation}

The tuff beds contain a significant proportion of volcanic material that makes them more interesting. These beds represent an important stratigraphic marker horizon for Kaimur group sedimentation. Zircon has been used, in particular, and can be a valuable aid in determining the precise ages of the containing tuff beds (Huff et al. 1997). Important advances have been made in generating reliable age data from the tuffaceous strata preserved within the Proterozoic basins of India (Rasmussen et al. 2002; Ray et al. 2002; Patranabis Deb et al. 2007; Das et al. 2009; Bickford et al. 2014, 2017; Mishra et al. 2018).

The Kaimur Group basinal sequences are intruded by $1073 \pm 13.7 \mathrm{Ma}$ Majhgawan kimberlite (Gregory et al. 2006). The kimberlite pipes, which intrude the Semri and Kaimur Groups, have been dated at $1140 \pm 112 \mathrm{Ma}$ (Paul et al. 1975) and $1067 \pm 31 \mathrm{Ma}$ (Kumar et al. 1993). Therefore, the age of the Kaimur group sedimentation have been constrained between 1100 and 1150 Ma (Kumar et al. 1993; Meert and Torsvik 2003; Gregory et al. 2006). Malone et al. (2008) inferred the closure age of the Vindhyan sedimentation was about $1000 \mathrm{Ma}$, with the age of the Kaimur sedimentation being around 1100 Ma. These ash beds are required to be dated as this could provide us the important clue to the initiation of the sedimentation of the Upper Vindhyan succession.

\section{Conclusions}

The tuffaceous beds and the siliciclastics sandwiching them from the Bijaigarh formation of the Kaimur group were studied. The field observations, petrography, mineralogy and geochemical characteristics of the Bijaigarh tuff have been compared with Bijaigarh shale from the Upper Kaimur group of the Vindhyan supergroup, to ascertain their diverse nature and processes of origin. The geochemical data of the Bijaigarh tuff have been compared with tuffs from (Singhora, Sukhda and Dhamda) Chhattisgarh and Indravati basins. Some of the key aspects are listed below:

a. The tuffaceous beds occur sandwiched within the Bijaigarh siliciclastics of the Kaimur Group, Vindhyan supergroup in Son valley, with a lateral continuity of about $10 \mathrm{~km}$.

b. On the basis of field disposition, petrographic and geochemical characteristics, magmatic origin can be inferred for the tuffaceous beds which can be distinctly distinguished from the adjacent detrital sediments of Bijaigarh shale.

c. Tuffs are rhyolitic to rhyodacitic in nature deposited in the within-plate type of tectonic setting with Bijaigarh siliciclastics. The mineralogical and geochemical data provide strong evidences for postdepositional K-metasomatism.

d. The paucity of evidences for intrabasinal volcanism during the sedimentation of the upper Kaimur group supports the deposition of volcanic ash beds from extrabasinal sources along with Bijaigarh sediments in a lagoonal environment.

e. Bijaigarh tuff when compared with tuffs from other Proterozoic basins reveals similarity in the geochemical signatures which is indicative of comparable sources. The presence of rhyolitic tuffs at $\sim 1000$ Ma may possibly be linked to probable large crustal-scale tectonothermal events taking place in the EGMB during the Grenville orogeny.

f. Tuffs will provide useful tools for correlation of the contemporaneous tuffs occurring in other 
Proterozoic basins of India, viz., Chhattisgarh, Indravati, etc. Integration of elemental compositions with mineralogical and textural observations makes possible the establishment of the tuffaceous beds as stratigraphic markers in the Upper Vindhyan stratigraphy. This would facilitate wider implications for the precise and reliable correlations of the Proterozoic basins of India.

\section{Acknowledgements}

The authors are grateful to University Grants Commission, New Delhi for the sanction of grant no. F. 31-196/2005 (SR) to MM. SS is thankful to the SERB-DST for providing financial support through project no. SR/FTP/ES-81/2014. We thank the editor for his editorial handling of the article. The comments made by two anonymous reviewers have greatly helped to revise and enrich this article.

\section{References}

Auden J B 1933 Vindhyan sedimentation in the Son valley, Mirzapur district; Mem. Geol. Soc. India 62(2) 141-250.

Balaram V, Ramesh S L and Anjaiah K V 1996 New trace element and REE data in thirteen GSF reference samples by ICP-MS; Geostand. News Lett. 20 71-78.

Balaram V, Gnaneswar Rao T and Anjaiah K V 1999 International proficiency tests for analytical geochemistry laboratories: An assessment of accuracy and precision in routine geochemical analysis; J. Geol. Soc. India 53 417-423.

Balasubramanyan M N and Chandy K C 1976 Lead isotope studies of galena from some occurrences in India; Rec. J. Geol. Surv. India 107 141-148.

Banerjee S, Dutta S, Paikaray S and Mann U 2006 Stratigraphy, sedimentology and bulk organic geochemistry of black shales from the Proterozoic Vindhyan Supergroup (central India); J. Earth Syst. Sci. 115 37-48.

Basu A, Patranabis-Deb S, Schieber J and Dhang P C 2008 Stratigraphic position of the $\sim 1000 \mathrm{Ma}$ Sukhda tuff (Chhattisgarh Supergroup, India) and the 500 Ma question; Precamb. Res. 167 383-388.

Bhattacharya A 1996 Recent advances in Vindhyan geology; Geol. Soc. India, Bangalore, 331p.

Bhattacharya A and Morad S 1993 Proterozoic braided ephemeral fluvial deposits: An example from the Dhandraul sandstone formation of the Kaimur group, Son valley, central India; Sedim. Geol. 84 101-114.

Bhowmik S K, Bernhardt H J and Dasgupta S 2010 Grenvillian age high-pressure upper amphibolite-granulite metamorphism in the Aravalli-Delhi Mobile belt, northwestern India: New evidence from monazite chemical age and its implication; Precamb. Res. 178 168-184.
Bickford M E, Basu A, Mukherjee A, Hietpas J, Schieber J, Patranabis-Deb S, Ray R K, Guhey R, Bhattacharya P and Dhang P C 2011a New U-Pb SHRIMP zircon ages of the Dhamda tuff in the Mesoproterozoic Chhattisgarh basin, Peninsular India: Stratigraphic implications and significance of a 1-Ga thermal-magmatic event; J. Geol. 119 $535-548$.

Bickford M E, Basu A, Patranabis-Deb S, Dhang P C and Schieber J 2011b Depositional history of the Chhattisgarh basin, central India: Constraints from new SHRIMP zircon ages; J. Geol. 119 33-50.

Bickford M E, Basu A, Kamenov G D, Mueller P A, Patranabis-Deb S and Mukherjee A 2014 Petrogenesis of 1000 Ma Felsic Tuffs, Chhattisgarh and Indravati Basins, Bastar Craton, India: Geochemical and Hf isotope constraints; J. Geol. 122 43-54.

Bickford E M, Mishra M, Mueller P A, Kamenov G D, Juergen $\mathrm{S}$ and Basu A 2017 U-Pb age and Hf-isotopic compositions of magmatic zircons from a rhyolite flow in the porcellanite formation in the Vindhyan supergroup, Son valley (India): Implications for its tectonic significance; J. Geol. 125 367-379.

Bora S, Kumar S, Yi K, Kim N and Lee Tae-Ho 2013 Geochemistry and U-Pb SHRIMP zircon chronology of granitoids and microgranular enclaves from Jhirgadandi Pluton of Mahakoshal Belt, Central India Tectonic Zone, India; J. Asian Earth Sci. 70-71 99-114.

Bose P K, Sarkar S, Chakraborty S and Banerjee S 2001 Overview of Meso- to Neoproterozoic evolution of the Vindhyan basin, central India; Sedim. Geol. 142 395-419.

Cas R A F and Wright J V 1991 Subaquoeus pyroclastic flows and ignimbrites: An assessment; Bull. Volcanol. 53 $357-380$.

Cashman K V and Fiske R S 1991 Fallout of pyroclastics debris from submarine volcanic eruption; Science $\mathbf{2 5 3}$ $275-280$.

Chakrabarti R, Basu A R and Chakrabarti A 2007 Trace element and Nd-isotopic evidence for sediment sources in mid-Proterozoic Vindhyan basin, central India; Precamb. Res. 159 260-274.

Chakraborty C 2006 Proterozoic intracontinental basin: The Vindhyan example; J. Earth Syst. Sci. 115 3-22.

Chakraborty C and Bose P K 1990 Internal structures of sandwave in a tide-storm interactive system: Proterozoic Lower Quartzite formation, India; Sedim. Geol. 67 133-142.

Chakraborty P P, Banerjee S, Das N G, Sarkar S and Bose P K 1996 Volcaniclastics and their sedimentological bearing in Proterozoic Kaimur and Rewa Groups in central India; In: Recent advances in Vindhyan geology (ed.) Bhattacharya A, Mem. Geol. Soc. India 36 59-76.

Chakraborty P P, Dey S and Mohanty S P 2010 Proterozoic platform sequences of peninsular India: Implications towards basin evolution and supercontinent assembly; J. Asian Earth Sci. 39 589-607.

Chanda S K and Bhattacharya A 1982 Vindhyan sedimentation and paleogeography: Post-Auden developments; In: Geology of Vindhyachal (eds) Valdiya K S, Bhatia S B and Gaur V K, Hindus. Pub. Corp., Delhi, pp. 88-101.

Chaudhuri A K and Chanda S K 1991 The Proterozoic of the Pranhita-Godavari valley: An overview; In: Sedimentary basins of India: Tectonic context (eds) Tandon S K, Pant C 
C and Casshyap S M, Gyanodaya Prakasan, Nainital, India, pp. 13-29.

Condie K C 1993 Chemical composition and evolution of the upper continental crust: Contrasting results from surface samples and shales; Chem. Geol. 104 1-37.

Cousineau P A 1994 Subaqueous pyroclastic deposition in an Ordovician forearc basin: An example from the SaintVictor formation, Quebec Appalachians, Canada; J. Sedim. Res. A64 867-880.

Coutinho J M V and Hachiro J 2005 Distribution, mineralogy, petrography, provenance and significance of Permian ashcarrying deposits in the Paraná basin; Rev. Inst. Geo. USP 5(1) 29-39.

Das K, Yokoyama K, Chakraborty P P and Sarkar A 2009 EPMA $\mathrm{U}-\mathrm{Th}-\mathrm{Pb}$ monazite dating and trace element geochemistry of tuff units from the basal part of Chhattisgarh and Khariar basin, central India: Implications for basin initiation and depositional contemporaneity; J. Geol. 117 88-102.

Dasgupta P K and Biswas A 2005 Rhythms in Proterozoic sedimentation: An example from peninsular India; Satish Serial Publishing House, Delhi, 240p.

Dypvik H 1979 Mineralogy and geochemistry of the Mesozoic sediments of Andya, Northern Norway; Sedim. Geol. 24 45-67.

Fedo C M, Nesbitt H W and Young G M 1995 Unraveling the effects of potassium metasomatism in sedimentary rocks and palaeosols, with implications for palaeoweathering conditions and provenance; Geology 23 921-924.

Fiore S 1993 The occurrences of smectite and illite in a pyroclastics deposit prior to weathering: Implications on the genesis of 2:1 clay minerals in volcanic soil; Appl. Clay Sci. 8 249-259.

Fisher R V and Schmincke H-U 1984 Pyroclastic rocks; Springer-Verlag, New York, 472p.

Foley S, Tiepolo M and Vannucci R 2002 Growth of early continental crust controlled by melting of amphibolite in subduction zones; Nature 417 837-840.

Gallala W, Essghaiser G M and Montacer M 2009 Detrital mode, mineralogy and geochemistry of the Sidi Aïch formation (Early Cretaceous) in central and southwestern Tunisia: Implications for provenance, tectonic setting and paleoenviroment; J. Afr. Earth Sci. 53 159-170.

García-Romero E, Vegas J, Baldonedo J L and Marfil R 2005 Clay minerals as alteration products in basaltic volcaniclastic deposits of La Palma (Canary Islands, Spain); Sedim. Geol. 174 237-253.

Gopalan K, Kumar A, Kumar B and Vijayagopal B 2013 Depositional history of the upper Vindhyan succession, central India: Time constraints from $\mathrm{Pb}-\mathrm{Pb}$ isochron ages of its carbonate components; Precamb. Res. 233 108-117.

Goswami S, Upadhyay P K, Bhagat S, Zakaulla S, Bhatt A K, Natarajan V and Dey S 2018 An approach of understanding acid volcanics and tuffaceous volcaniclastics from field studies: A case from Tadpatri formation, Proterozoic Cuddapah basin, Andhra Pradesh, India; J. Earth Syst. Sci. 127 20, https://doi.org/10.1007/s12040-018-0929-0.

Gregory L C, Meert J G, Pradhan V, Pandit M K, Tamrat E and Malone S J 2006 A paleomagnetic and geochronologic study of the Majhgawan Kimberlite, India: Implications for the age of the Vindhyan supergroup; Precamb. Res. 149 65-75.

Heiken G and Wohletz K 1985 Volcanic ash; Univ. of California Press, Berkeley, 256p.
Huff W D, Kolata D R, Bergström S M and Zhang Y S 1996 Large-magnitude Middle Ordovician volcanic ash falls in North America and Europe: Dimensions, emplacement and post emplacement characteristics; J. Volcanol. Geotherm. Res. 73 285-301.

Huff W D, Davis D W, Bergstr M S M, Krekeler M P S, Kolata D R and Cingolani C 1997 A biostratigraphically well constrained K-bentonite U-Pb zircon age of the lowermost Darriwilian stage (Middle Ordovician) from the Argentine Precordillera; Episodes 20 29-33.

Kah L C and Riding R 2007 Mesoproterozoic carbon dioxide levels inferred from calcified cyanobacteria; Geology 35799.

Kumar S 2001 Mesoproterozoic megafossil Chuaria - Tawuia association may represent parts of a multicellular plant, Vindhyan supergroup, central India; Precamb. Res. 106 187-211.

Kumar A, Kumari P, Dayal A M, Murthy D S N, Gopalan K $1993 \mathrm{Rb}-\mathrm{Sr}$ ages of Proterozoic kimberlites of India: Evidence for contemporaneous emplacements; Precamb. Res. 62 227-237.

Kumar A, Gopalan K and Rajgopalan G 2001 Age of the Lower Vindhyan sediments, Central India; Curr. Sci. 81 806-809.

Malone S J, Meert J G, Banerjee D M, Pandit M K, Tamrat E, Kamenov G D, Pradhan V R and Sohl L E 2008 Paleomagnetism and detrital zircon geochronology of the Upper Vindhyan sequence, Son valley and Rajasthan, India: A ca. 1000 Ma closure age for the Purana basins?; Precamb. Res. 164 137-159.

McLennan S M 1989 Rare earth elements in sedimentary rocks, influence of provenance and sedimentary processes; In: Geochemistry and mineralogy of rare earth elements (eds) Lipin B R and MacKay G A, Miner. Soc. Am. 169-200.

McLennan S M, Hemming S, McDanniel D K and Hanson G N 1993 Geochemical approaches to sedimentation, provenance, and tectonics; In: Processes controlling the composition of clastic sediments (eds) Johnsson M J and Basu A, Geol. Soc. Am. Spec. Paper 285 21-40.

McPhie J, Doyle M and Allen R 1993 Volcanic textures: A guide to the interpretation of textures in volcanic rocks; CODES Key Centre, University of Tasmania, Hobart, 198p.

Meert J G and Torsvik T H 2003 The making and unmaking of a supercontinent: Rodinia revisited; Tectonophys. $\mathbf{3 7 5}$ 261-288.

Mishra M and Sen S 2008 Geochemistry and origin of Proterozoic porcellanitic shales from Chopan, Vindhyan basin, India; Ind. J. Geol. 80(1-4) 157-171.

Mishra M and Sen S 2011 Geochemical signatures for the grain size variation in the siliciclastic rocks of Kaimur group, Vindhyan supergroup from Markundi ghat, Sonbhadra district (UP), India; Geochem. Int. 49(3) 274-290.

Mishra M and Sen S 2012 Provenance, tectonic setting and source-area weathering of Mesoproterozoic Kaimur group, Vindhyan supergroup, central India; Geol. Acta 10(3) 243-253.

Mishra M and Sen S 2015 Geochemistry of Rohtas limestone from Vindhyan supergroup, central India: Evidences of detrital input from felsic source; Geochem. Int. 53(12) 1107-1122.

Mishra M, Sen S and Kumari K 2017a Explosive felsic volcanism at Palaeo-Mesoproterozoic boundary from 
Vindhyan supergroup, Son valley, central India - evidences of crustal contamination; Geochem. Int. 55 474-488.

Mishra M, Srivastava V, Sinha P K and Srivastava H B 2017b Geochemistry of Mesoproterozoic Deonar pyroclastics from Vindhyan supergroup of central India: Evidences of felsic magmatism in the Son valley; J. Geol. Soc. Ind. 89 375-385.

Mishra M, Srivastava V and Srivastava H B 2017c A report on the occurrence of ferruginous breccia in Chopan porcellanite formation from Semri group, Sonbhadra district (UP); $J$. Sci. Res. Banaras Hindu Univ. 61 1-11.

Mishra M, Bickford M E and Basu A 2018 U-Pb Age and chemical composition of an Ash Bed in the Chopan porcellanite formation, Vindhyan supergroup, India; $J$. Geol. 126 553-560.

Mukherjee A, Bickford M E, Hietpas J, Schieber J and Basu A 2012 Implications of a newly dated ca 1000 Ma rhyolitic tuff in the Indravati basin, Bastar Craton, India; J. Geol. 120(4) 477-543.

Nadeau P H and Reynolds Jr R C 1981 Volcanic components in politic sediments; Nature 294 72-74.

Nemeth K 2010 Volcanic glass textures, shape characteristics and compositions from phreatomagmatic rock units of the western Hungarian monogenetic volcanic fields and their implication to magma fragmentation; Cen. Eur. J. Geosci. 2(3) 399-419.

Nesbitt H W and Young G M 1984 Prediction of some weathering trends of plutonic and volcanic rocks based on thermodynamic and kinetic considerations; Geochim. Cosmochim. Acta 48 1523-1534.

Paikaray S, Banerjee S, Kumar J and Mukherjee S 2003 Occurrences of black shales within the Vindhyan supergroup, central India and its implications; Ind. J. Petrol. Geol. 12(2) 65-81.

Paikaray S, Banerjee S and Mukherji S 2005 Sorption of arsenic onto Vindhyan shales, role of pyrite and organic carbon; Curr. Sci. 88(10) 1580-1581.

Parnell J and Foster S 2012 Ordovician ash geochemistry and the establishments of land plants; Geochem. Trans. 13 1-7.

Patranabis Deb S 2003 Proterozoic felsic volcanism in the Pranhita-Godavari valley, India: Its implication on the origin of the basin; J. Asian Earth Sci. 21 623-631.

Patranabis Deb S, Bickford M E, Hill B, Chaudhuri A K and Basu A 2007 SHRIMP ages of zircon in the uppermost tuff in Chhattisgarh basin in central India require $\sim 500$ Ma adjustment in Indian Proterozoic stratigraphy; J. Geol. 115 $407-415$.

Paul D K, Rex D C and Harris P G 1975 Chemical characteristics and K-Ar ages of Indian kimberlites; Geol. Soc. Amer. Bull. 86 364-366.

Pearce J A, Harris N B W and Tindle A G 1984 Trace element discrimination diagrams for the tectonic interpretation of granitic rocks; J. Petrol. 25 956-983.

Poma S, Litvak V D, Koukharsky M, Maisonnave E B and Quenardelle S 2009 Darwin's observation in South America: What did he find at agua de la zorra, Mendoza province?; Rev. Assoc. Geol. Argentina 64(1) 13-20.

Prakash R and Dalela S 1982 Stratigraphy of the Vindhyan in Uttar Pradesh: A brief review; In: Geology of Vindhyachal (ed.) Valdiya K S et al., Hindustan Publishing Corp. (India), New Delhi, pp. 55-79.

Prasad B R and Rao V V 2006 Deep seismic reflection study over the Vindhyans of Rajasthan: Implications for the geophysical setting of the basin; J. Earth Syst. Sci. 115 $135-147$.

Rasmussen B, Bose P K, Sarkar S, Banerjee S, Fletcher I R and McNaughton N J 20021.6 ga U-Pb zircon age for the Chorhat sandstone, lower Vindhyan, India: Possible implications for early evolution of animals; Geology 30 103-106.

Ray J S, Martin M W, Veizer J and Bowring S A 2002 U-Pb zircon dating and $\mathrm{Sr}$ isotope systematics of the Vindhyan supergroup, India; Geology 30 131-134.

Rino S, Kon Y, Sato W, Maruyama S, Santosh M and Zhao D 2008 The Grenvillian and Pan-African orogens: World's largest orogenies through geologic time, and their implications on the origin of superplume; Gond. Res. 14 51-72.

Rogers J J W and Santosh M 2004 Continents and supercontinents; Oxford, New York, 289p.

Roy S and Banerjee S 2001 Facies and petrography of the Porcellanite formation around Chopan, Uttar Pradesh; J. Ind. Assoc. Sediment. 20(2) 195-205.

Roy A, Kagami H, Yoshida M, Roy A, Bandyopadhyay B K, Chattopadhyay A $2006 \mathrm{Rb} / \mathrm{Sr}$ and $\mathrm{Sm} / \mathrm{Nd}$ dating of different metamorphic events from the Sausar mobile belt, central India; implications for Proterozoic crustal evolution; J. Asian Earth Sci. 26 61-76.

Saha D and Ghosh G 1998 Lithostratigraphy of deformed Proterozoic rocks from around the confluence of Godavari and Indravati rivers, South India; Ind. J. Geol. 70 217-230.

Saha D and Tripathy V 2012 Tuff beds in Kurnool subbasin, southern India and implications for felsic volcanism in Proterozoic intracratonic basins; Geosci. Front. 3(4) 429-444.

Sarangi S, Gopalan K and Kumar S 2004 Pb-Pb age of earliest megascopic, eukaryotic alga bearing Rhotas formation, Vindhyan supergroup, India: Implications for Precambrian atmospheric oxygen evolution; Precamb. Res. 132 107-121.

Sarkar A, Paul D K and Potts P J 1995 Geochronology and geochemistry of the Mid-Archean trondhjemitic gneisses from the Bundelkhand craton, Central India; In: Recent Researchers in Geology (ed.) Saha A K, Hindustan Publ. Co., Delhi, pp. 76-92.

Sarkar S, Banerjee S, Samanta P and Jeevankumar S 2006 Microbial mat-induced sedimentary structures in siliciclastic sediments: Examples from the 1.6 Ga Chorhat sandstone, Vindhyan supergroup, M.P., India; J. Earth Sys. Sci. 115 49-60.

Schieber J 2004 Microbial mats in the siliciclastic rock record: A summary of diagnostic features; In: The Precambrian earth: Tempos and events (eds) Eriksson P G, Altermann P G, Nelson D R, Mueller W U and Catuneanu O, Elsevier, Amsterdam, pp. 663-673.

Schmid R 1981 Descriptive nomenclature and classification of pyroclastic deposits and fragments: Recommendations of the IUGS subcommission on the systematics of igneous rocks; Geology 9 41-43.

Self S 2006 The effects and consequences of very large explosive volcanic eruptions; Phil. Trans. Roy. Soc. 364 2073-2097.

Sen S 2010 Geochemistry and provenance of the siliciclastics from Kaimur group, Vindhyan supergroup, Mirzapur and Sonbhadra Districts, Uttar Pradesh, India; PhD Thesis, Banaras Hindu University, Varanasi, 221p.

Sen S and Mishra M 2014 Tuffaceous bed from Bijaigarh Shale, Vindhyan Supergroup, Central India: An evidence of volcanism; Proc. of IAGR conference series serial no. 18, Nainital, 55p. 
Sen S, Mishra M and Patranabis-Deb S 2014 Petrological study of the Kaimur group sediments, Vindhyan supergroup, central India: Implications for provenance and tectonics; Geosci. J. 18(3) 307-324.

Shoji S, Nanzyo M and Dahlgren R A 1993 Volcanic Ash soils: Genesis, properties and utilization; In: Development in soil science; Vol. 21, Elsevier, Amsterdam, pp. 1-288.

Singh I B 1980 Precambrian sedimentary sequences of India: Their peculiarities and comparison with modern sediment; Precamb. Res. 12 411-436.

Soni M K, Chakraborty S and Jain V K 1987 Vindhyan supergroup - A review. In: Purana basins of peninsular India (Middle to Late Proterozoic); Mem. Geol. Soc. India 6 87-138.

Srivastava A P and Rajagopalan G 1988 F-T ages of Vindhyan glauconitic sandstone beds exposed around Rawatbhata area, Rajasthan; J. Geol. Soc. India 32 $527-529$.

Srivastava R N, Srivastava A K, Singh K N and Redcliffe R P 2003 Sedimentation and depositional environment of the Chopan porcellanite formation, Semri group, Vindhyan supergroup in parts of Sonbhadra district, Uttar Pradesh; J. Palaeontol. Soc. India 48 167-179.

Subba Rao D V, Mukherjee A, Khan M W Y and Sridhar D N 2006 New occurrence of intrabasinal ignimbrites and welded tuffs from NE part of the Meso- to Neoproterozoic Chattisgarh basin, Bastar craton: Implications for petrogenesis; J. Geol. Soc. India 68 589-595.

Sun S-S and McDonough W F 1989 Chemical and isotopic systematics of oceanic basalts: Implications for mantle composition and processes; In: Magmatism in the ocean basins (eds) Saunders A D and Norry M J, Geol. Soc. Spec. Publ. 42 313-345.

Sur S, Schieber J and Banerjee S 2006 Petrographic observations suggestive of microbial mats from Rampur shale and
Bijaigarh shale, Vindhyan basin, India; J. Earth Syst. Sci. 115 61-66.

Tajika E 2003 Faint young Sun and the carbon cycle: Implication for the Proterozoic global glaciations; Earth Planet. Sci. Lett. 214 443-453.

Taylor S R and McLennan S M 1985 The continental crust: Its composition and evolution; Blackwell, London, 311p.

Tripathy G R and Singh S K 2015 Re-Os depositional age for black shales from the Kaimur group, Upper Vindhyan, India; Chem. Geol. 413 63-72.

Turner C C, Meert J G, Pandit M K and Kamenov G D 2014 A detrital zircon $\mathrm{U}-\mathrm{Pb}$ and $\mathrm{Hf}$ isotopic transect across the Son valley sector of the Vindhyan basin, India: Implications for basin evolution and paleogeography; Gond. Res. 26 $348-364$.

Valdiya K S, Bhatia S B and Gaur V K 1982 Geology of Vindhyachal: A volume in honour of Prof. R. C. Mishra; Hindustan Publishing Corp. India, New Delhi.

Veevers J J and Saeed A 2009 Permian-Jurassic Mahanadi and Pranhita-Godavari rifts of Gondwana India: Provenance from regional paleoslope and $\mathrm{U}-\mathrm{Pb} / \mathrm{Hf}$ analysis of detrital zircons; Gond. Res. 16 633-654.

Weaver C E and Beck K C 1977 Miocene of the S.E. United States: A model for chemical sedimentation in a peri-marine environment; Sedim. Geol. 17 1-234.

Winchester J A and Floyd P A 1976 Geochemistry discrimination of different magma series and their differentiation products using immobile elements; Chem. Geol. 20 $325-343$.

Wright J V and Mutti E 1981 The Dali ash, islands of Rhodes, Greece: A problem in interpreting submarine volcanogenic sediments; Bull. Volcanol. 44 153-167.

Young G M 1995 Are neoproterozoic glacial deposits preserved on the margins of Laurentia related to the fragmentation of two super continents?; Geology 23 153-156.

Corresponding editor: N V Chalapathi RaO 